\title{
Pacific Proving Grounds radioisotope imprint in the Philippine Sea sediments
}

\author{
Pittauer, Daniela; Roos, Per; Qiao, Jixin; Geibert, Walter; Elvert, Marcus; Fischer, Helmut W.
}

Published in:

Journal of Environmental Radioactivity

Link to article, DOI:

10.1016/j.jenvrad.2017.06.021

Publication date:

2018

Document Version

Peer reviewed version

Link back to DTU Orbit

Citation (APA):

Pittauer, D., Roos, P., Qiao, J., Geibert, W., Elvert, M., \& Fischer, H. W. (2018). Pacific Proving Grounds radioisotope imprint in the Philippine Sea sediments. Journal of Environmental Radioactivity, 186, 131-141. https://doi.org/10.1016/j.jenvrad.2017.06.021

\section{General rights}

Copyright and moral rights for the publications made accessible in the public portal are retained by the authors and/or other copyright owners and it is a condition of accessing publications that users recognise and abide by the legal requirements associated with these rights.

- Users may download and print one copy of any publication from the public portal for the purpose of private study or research.

- You may not further distribute the material or use it for any profit-making activity or commercial gain

- You may freely distribute the URL identifying the publication in the public portal 


\title{
Manuscript Details
}

Manuscript number

Title

Article type
JENVRAD_2017_184

Pacific Proving Grounds radioisotope imprint in the Philippine Sea sediments

Research Paper

\section{Abstract}

Radionuclide concentrations were studied in sediment cores taken at the continental slope of the Philippine Sea off Mindanao Island in the equatorial Western Pacific. High resolution deposition records of anthropogenic radionuclides were collected at this site. Excess $210 \mathrm{~Pb}$ together with excess 228Th and anthropogenic radionuclides provided information about accumulation rates. Concentrations of Am and Pu isotopes were detected by gamma spectrometry, alpha spectrometry and ICP-MS. The Pu ratios indicate a high portion (minimum of 60\%) of Pu from the Pacific Proving Grounds (PPG). This implies that the transport of PPG derived plutonium with the Mindanao Current southward is similarly effective as the previously known transport towards the north with the Kuroshio Current. The record is compared to other studies from northwest Pacific marginal seas and Lombok basin in the Indonesian Archipelago. The sediment core top was found to contain a $6 \mathrm{~cm}$ thick layer dominated by terrestrial organic matter, which was interpreted as a result of the 2012 Typhoon Pablo-related fast deposition.

Keywords

Taxonomy

Corresponding Author

Corresponding Author's Institution

Order of Authors

Suggested reviewers
241Am; 137Cs; plutonium; excess 228Th; typhoon; Pacific Ocean

Environmental Monitoring, Radioactivity in Marine Environment, Environmental Analysis

Daniela Pittauer

MARUM - Center for Marine Environmental Sciences, University of Bremen

Daniela Pittauer, Per Roos, Jixin Qiao, Walter Geibert, Marcus Elvert, Helmut W. Fischer

Jose Corcho, Shaoming Pan, Patric Lindahl

\section{Submission Files Included in this PDF}

\author{
File Name [File Type] \\ Pittauer-Philippine.pdf [Manuscript (without Author Details)] \\ map.pdf [Figure] \\ natural.PDF [Figure] \\ artificial.PDF [Figure] \\ org.PDF [Figure] \\ age.pdf [Figure] \\ artificial_2.PDF [Figure] \\ comparison.pdf [Figure] \\ highlights.pdf [Highlights] \\ Supplemet_Data.xlsx [Supporting File] \\ Pittauer_Supplement.pdf [Supporting File] \\ Front_Pittauer-Philippines.pdf [Title Page (with Author Details)]
}

To view all the submission files, including those not included in the PDF, click on the manuscript title on your EVISE Homepage, then click 'Download zip file'. 


\title{
Pacific Proving Grounds radioisotope imprint in the Philippine Sea sediments
}

\begin{abstract}
Radionuclide concentrations were studied in sediment cores taken at the continental slope of the Philippine Sea off Mindanao Island in the equatorial Western Pacific. High resolution deposition records of anthropogenic radionuclides were collected at this site. Excess ${ }^{210} \mathrm{~Pb}$ together with excess ${ }^{228} \mathrm{Th}$ and anthropogenic radionuclides provided information about accumulation rates. Concentrations of Am and Pu isotopes were detected by gamma spectrometry, alpha spectrometry and ICP-MS. The Pu ratios indicate a high portion (minimum of 60\%) of Pu from the Pacific Proving Grounds (PPG). This implies that the transport of PPG derived plutonium with the Mindanao Current southward is similarly effective as the previously known transport towards the north with the Kuroshio Current. The record is compared to other studies from northwest Pacific marginal seas and Lombok basin in the Indonesian Archipelago. The sediment core top was found to contain a $6 \mathrm{~cm}$ thick layer dominated by terrestrial organic matter, which was interpreted as a result of the 2012 Typhoon Pablo-related fast deposition.
\end{abstract}

Keywords: ${ }^{241} \mathrm{Am},{ }^{137} \mathrm{Cs}$, plutonium, excess ${ }^{228} \mathrm{Th}$, typhoon, Pacific Ocean

\section{Introduction}

From 1946 to 1958 the United States conducted an extensive nuclear test programme at Bikini and Enewetak atolls, Marshall Islands (Fig. 1), which were part of the Pacific Proving Grounds (PPG). At the Marshall Islands, 65 atmospheric and underwater tests were performed, many of them with high yield. Approximately $70 \%$ of the total yield of all U.S. atmospheric tests were performed at these two atolls, causing a high degree of local and regional fallout. In fact, because the nuclear explosions were performed at or close to ground level or underwater, Bikini and Enewetak account for $96 \%$ of local and regional nuclear tests fission yield globally (UNSCEAR, 2000). An estimated $90 \mathrm{TBq}$ of ${ }^{239+240} \mathrm{Pu}$ have been deposited in the atoll lagoons' sediments and they represent an important secondary regional source of anthropogenic radionuclides. Plutonium is continuously being released into the open ocean with a rate of approximately $0.2 \mathrm{TBq} \cdot \mathrm{yr}^{-1}$ (Lindahl et al., 2010).

Another significant plutonium source in the marine environment is the integrated global fallout from nuclear explosions in the atmosphere. The tests injected radionuclide particles into the stratosphere, in which they were dispersed and deposited worldwide (Hamilton, 2005). The first significant insertion of radionuclides into the stratosphere was connected with the 1952 Ivy Mike thermonuclear test. Nuclear testing in the atmosphere continued until a three year moratorium on all nuclear testing between 1958 and 1961, and was resumed until October 1963, when the partial nuclear test ban treaty came into effect. The most intensive years regarding atmospheric testing were between 1961 and 1963, mainly due to a large contribution from the U.S.S.R. high yield tests at Novaya Zemlya. Later fallout from Chinese tests at Lop Nor 1964-1980 and French tests in French Polynesia 1966-1974 contributed comparatively little to the fallout (UNSCEAR, 2000). The estimated ${ }^{239+240} \mathrm{Pu}$ inventory in the North Pacific from the global fallout is presumed to be $6 \mathrm{PBq}$ (Lindahl et al., 2010).

Apart from the integrated global fallout and the PPG, an additional source of ${ }^{238} \mathrm{Pu}$ in the sediments in the tropical Pacific is fallout from the navigation satellite SNAP-9A with a ${ }^{238} \mathrm{Pu}$ radioisotope thermoelectric generator on-board, which burned up in the atmosphere at the altitude of $50 \mathrm{~km}$ above the Indian Ocean in 1964 (Krey, 1967; Hardy et al., 1973; Harley, 1980). This introduction of additional ${ }^{238} \mathrm{Pu}$ has changed the ${ }^{238} \mathrm{Pu} /{ }^{239+240} \mathrm{Pu}$ activity ratios globally. A higher portion, about $78 \%$ of the estimated $0.63 \mathrm{PBq}$ of ${ }^{238} \mathrm{Pu}$, was deposited in the southern hemisphere (Lindahl et al., 2010), where it can be used as a useful time marker in sediment cores (Hancock et al., 2011). However, in the latitudinal band of $0-10^{\circ} \mathrm{N}$, a negligible contribution from this source is expected (Hardy et al., 1973).

Artificial radionuclides remain in the Pacific Ocean water column many years after their initial arrival, and their distribution is characterized by a subsurface maximum at depth between 500 and 1,000 m (Povinec et al., 2003). Availability of particles near the continental margin due to higher productivity and suspended particle load, supports 
A

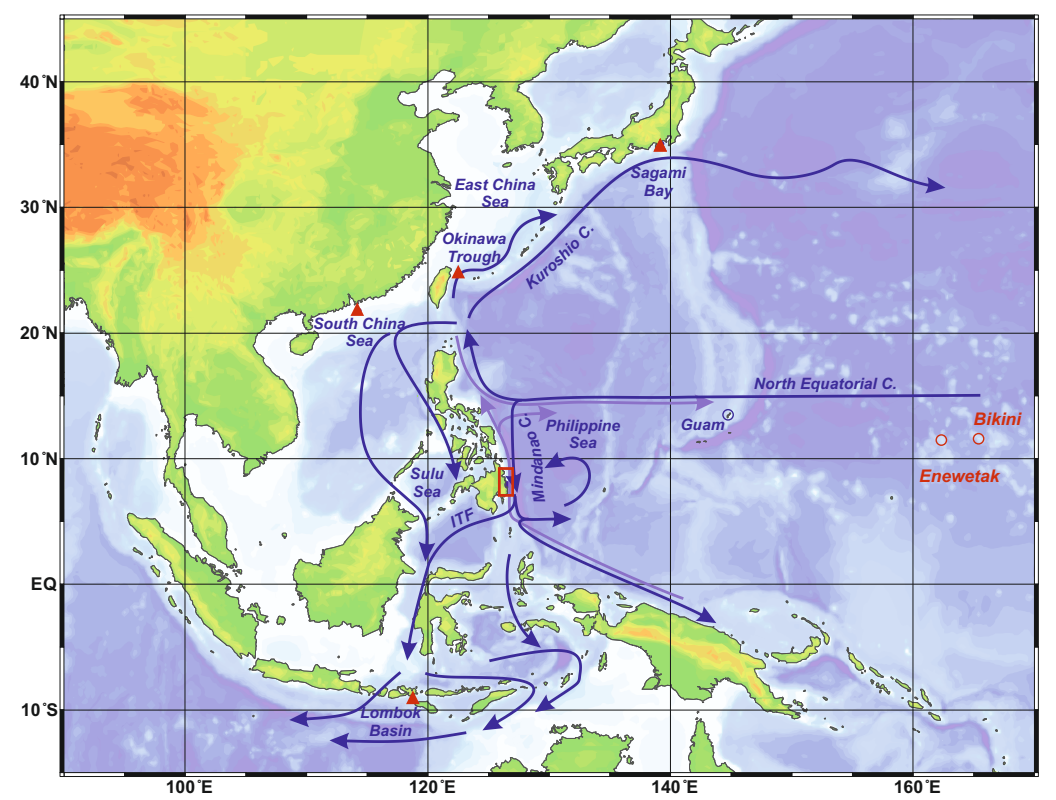

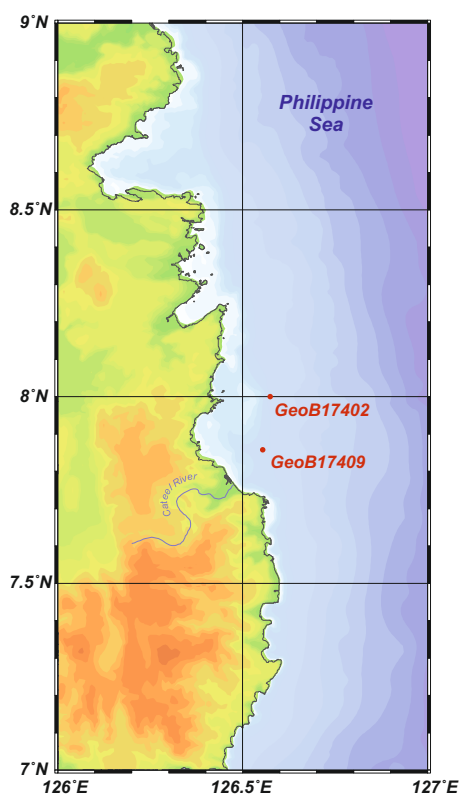

Figure 1: (A) Overview map of the NW Pacific with the principal currents, plotted after Hu et al. (2015). The study site at the Mindanao continental slope is highlighted by a red rectangle. The previous studies referred to in Section 4.5 are marked by triangles. (B) Detail of the Mindanao east coast with locations of the sampling sites off Cateel, Davao Oriental province. This map was created in Ocean Data View software (Schlitzer, 2016).

particle-reactive radionuclides $\left({ }^{241} \mathrm{Am}\right.$ and plutonium isotopes) scavenging from the water column and their incorporation in the sediment (León Vintró et al., 2005). Conversely, depth distribution of artificial radionuclides in fast depositing anthropogenic sediment layers can provide information about changes of radioisotope concentration in the overlying water column in time, and activity and atom ratios of anthropogenic radionuclides contain information about their origin. Inventories $\left(\mathrm{Bq} \cdot \mathrm{m}^{2}\right)$ of these transient signals relative to steady state tracers like ${ }^{210} \mathrm{~Pb}$ thus provide information on the magnitude of the sediments as sinks for a particular source. Elsewhere, plutonium isotopes have successfully been used as chronometers in Anthropocene sediment cores (Corcho-Alvarado et al., 2014).

Bikini and Enewetak atolls are located along the pathway of the North Equatorial Current (NEC), a westward moving major current, forming the southern boundary of the clockwise northern subtropical gyre. The NEC reaches the continental margin in the Philippine Sea and bifurcates into the northbound Kuroshio Current (KC) and the southbound Mindanao Current (MC). This current splitting takes place about $14^{\circ} \mathrm{N}$ at the surface and $20^{\circ} \mathrm{N}$ at a depth of $1,000 \mathrm{~m}$ (Hu et al., 2015). Qu \& Lukas (2003) estimated the average partition of MC and KC as $31.4 \mathrm{~Sv}$ and 25.4 $\mathrm{Sv}\left(1 \mathrm{~Sv}=10^{6} \mathrm{~m}^{2} \mathrm{~s}-1\right)$, respectively, while large inter-seasonal variations were observed. The MC therefore carries North Pacific water masses southward, partially diverging them towards the Indonesian Throughflow. Below the thermocline, the Mindanao Undercurrent transports water of South Pacific origin northward. This poleward transport however happens in a greater distance from the Mindanao coast; within $50 \mathrm{~km}$ from the shore the transport in southward direction occurs up to a depth of 1,000 m (Schönau et al., 2015).

Plutonium isotopes are reportedly being distributed from the PPG by the NEC and the KC towards the Pacific Ocean marginal seas, particularly in the East China Sea (Wang et al., 2017; Tims et al., 2010; Wang \& Yamada, 2005; Lee et al., 2004) and along the Japanese west coast (e.g., Zheng \& Yamada, 2004). Clear PPG signals are also reported in sediments from the Sulu and South China Seas (Dong et al., 2010; Wu et al., 2014). Recently, the PPG derived transuranics were found in the sediments of the Lombok basin off the Indonesian island of Sumba (Steinke et al., 2014; Pittauer et al., 2017). The transport likely follows the pathway southward with the Mindanao Current, and further through the Maritime Continent.

Up to this date, artificial radionuclide deposition history and the PPG effect has not been explored in the Philippine 
Sea, in the area south of the NEC bifurcation. Within this study we aim to examine the sources of artificial radionuclides in the continental slope sediment cores off the Philippine southern island of Mindanao (Fig. 1) and quantify the portion of PPG derived plutonium versus integrated global fallout, as well as the contribution from SNAP-9A. The acquired results are put into context with previously examined sites north from the NEC bifurcation and south of it.

\section{Material and methods}

\subsection{Sampling location}

The sampling sites were located in the Cateel Bay, at the continental slope of the Philippine Sea east of Mindanao (Table 1, Fig. 1). Two sediment cores were analyzed in this work. The core GeoB17402 was taken about $13 \mathrm{~km}$ east of the Surigao del Sur coast. The coring location GeoB17409 was situated about $13 \mathrm{~km}$ north-east from the Cateel river delta in Davao Oriental province. The Cateel river descends from steep mountains through a tropical lowland rainforest (Aliwagwag Protected Landscape), followed by a narrow floodplain and a delta.

The ocean bottom below the shelf is characterized by a rugged relief, with deep canyons, which do not seem to be connected to the existing river system, slope failures and rotational slumps. The locations of coring sites were selected based on seismo-acoustic surveys so that they contain at least several meters of layered sediments. Both sites GeoB17402 and GeoB17409 were situated on terraces between the canyons (Schwenk, 2017).

\subsection{Sampling and sample preparation}

The sediment cores were taken during the German R/V Sonne cruise SO-228 in 2013 (Mohtadi \& cruise participants, 2013) by multi-corer. The cores (diameter of $60 \mathrm{~mm}$ ) were sliced on-board to $1 \mathrm{~cm}$ depth increments, filled into cylindrical plastic dishes with a diameter of $70 \mathrm{~mm}$ and sealed using radon-tight aluminium barrier foil (Pittauerová et al., 2014) for later gamma-spectrometric analysis. The samples were measured wet. Before taking sub-samples for further analyses, the samples were lyophilized and water content and dry bulk density were determined (see Supplementary online material).

Table 1: Summary of sampling data.

\begin{tabular}{lccccc}
\hline Sediment cores & Sampling date & Latitude $(\mathrm{N})$ & Longitude $(\mathrm{E})$ & Water depth $(\mathrm{m})$ & Core recovery $(\mathrm{cm})$ \\
\hline GeoB17402 & 11.05 .2013 & $+8^{\circ} 0.03^{\prime}$ & $126^{\circ} 34.50^{\prime}$ & 553 & 18 \\
GeoB17409 & 14.05 .2013 & $+7^{\circ} 51.50^{\prime}$ & $126^{\circ} 33.28^{\prime}$ & 503 & 33 \\
\hline
\end{tabular}

\subsection{Gamma spectrometry}

Natural and anthropogenic radionuclides were analyzed by gamma spectrometry at the Institute of Environmental Physics (IUP), University of Bremen. Before starting measurement, the sealed samples were stored for a minimum of 3 weeks so that radioactive equilibrium between ${ }^{226} \mathrm{Ra}$ and ${ }^{222} \mathrm{Rn}$ (and its daughters) had been established. Information on slicing, sample masses and measurement times are available in the Supplementary online material, as well as further details on gamma spectra analysis. A reverse electrode coaxial HPGe detector (Canberra Industries, $50 \%$ rel. efficiency) with a carbon-composite window housed in a $10 \mathrm{~cm} \mathrm{~Pb}$ shielding with $\mathrm{Cu}, \mathrm{Cd}$ and plastic lining operated with Genie 2000 software was used for gamma spectroscopy. The efficiencies were calculated using LabSOCS (Laboratory SOurceless Calibration System), a Genie 2000 software calibration tool, based on defined sample to detector geometry and sample density and composition, including water content, for a factory characterized detector. They were verified using measurements of certified materials in similar geometries. The overall uncertainties combine errors arising from counting statistics, efficiency calibration, sample mass determination and decay data.

Excess ${ }^{210} \mathrm{~Pb}\left({ }^{210} \mathrm{~Pb}_{x s}\right)$ values were calculated by subtracting supported ${ }^{210} \mathrm{~Pb}$, assumed to be in equilibrium with ${ }^{226} \mathrm{Ra}$, from total ${ }^{210} \mathrm{~Pb}$. Other reported natural gamma emitting radionuclides include ${ }^{40} \mathrm{~K},{ }^{228} \mathrm{Ra}$ and ${ }^{228} \mathrm{Th}$. The excess of ${ }^{228} \mathrm{Th}\left({ }^{228} \mathrm{Th}_{x s}\right)$ over ${ }^{228} \mathrm{Ra}$ was calculated as a difference of both values and used as a measure of radioactive disequilibrium in the Th decay chain. Two anthropogenic gamma emitters were detected: ${ }^{241} \mathrm{Am}$ and ${ }^{137} \mathrm{Cs}$. 


\subsection{Radiochemical separation of $P u$}

Sub-samples of core GeoB17409 (approx. $10 \mathrm{~g}$ dry weight) were ashed overnight at $550^{\circ} \mathrm{C}$ and spiked with a ${ }^{242} \mathrm{Pu}$ tracer $\left(0.1037 \mathrm{~Bq} \cdot \mathrm{g}^{-1}\right.$ solution in $2 \mathrm{~mol} \cdot \mathrm{l}^{-1} \mathrm{HNO}_{3}$ diluted from NBL-CRM 130 by New Brunswick Laboratory, Argonne, IL). The samples were leached with Aqua regia and Pu was separated by co-precipitation following a method described in Qiao et al. (2011). The sample solutions, adjusted to $8 \mathrm{~mol} \cdot \mathrm{l}^{-1} \mathrm{HNO}_{3}$, were passed through a $12 \mathrm{~cm}$ long AG 1-X4 (Bio-Rad, 100-200 mesh) resin column preconditioned with $8 \mathrm{~mol} \cdot \mathrm{l}^{-1} \mathrm{HNO}_{3}$. The columns were rinsed with $100 \mathrm{ml}$ of $8 \mathrm{~mol} \cdot \mathrm{l}^{-1} \mathrm{HNO}_{3}$ to remove matrix elements $(\mathrm{Ca}, \mathrm{Mg}, \mathrm{Fe}, \mathrm{Pb})$, as well as $\mathrm{Am}$ and $\mathrm{U}$, followed by 100 $\mathrm{ml}$ of $9 \mathrm{~mol} \cdot \mathrm{l}^{-1} \mathrm{HCl}$, which released Th. Finally Pu was eluted by $0.5 \mathrm{~mol} \cdot \mathrm{l}^{-1} \mathrm{HCl}$. To ensure the purity of $\mathrm{Pu}$, the anion exchange chromatographic separation with AG 1-X4 was repeated using shorter columns $(5 \mathrm{~cm})$.

\subsection{Alpha spectrometry}

Plutonium was electroplated to stainless steel discs using the method of Hallstadius (1984). Plutonium isotopes were measured by alpha spectrometry in core GeoB17409 at IUP and Alfred Wegener Institute (AWI) for Polar and Marine Research in Bremerhaven, Germany, using passivated implanted planar silicon detectors (PIPS) in vacuum chambers. Spectra were analyzed by Genie 2000 software. A method of peak fitting was used, as in some cases it was necessary to de-convolute the overlapping peaks of ${ }^{238} \mathrm{Pu}$ from ${ }^{228} \mathrm{Th}$, present in small quantities in the background of the IUP detectors and in some samples due to Th-series impurities left after chemical extraction. The overall uncertainties combine errors arising from peak fitting, sample mass determination and spike activity (5\%).

After alpha counting, Pu was washed off the stainless plates with drops of concentrated $\mathrm{HCl}$ and $\mathrm{HNO}_{3}$. The solution was purified by a short AG 1-X4 anion exchange column, before being used for mass spectrometric analysis.

\subsection{Mass spectrometry}

Plutonium isotopes were analyzed by inductively coupled plasma mass spectrometry (ICP-MS) at the Center for Nuclear Technologies (NUTECH), Technical University of Denmark in Roskilde, using the Agilent 8800 with standard $\mathrm{x}$-cones and an APEX-Q with a Micromist nebuliser at sample uptake rate of $200 \mu \mathrm{l}$ per minute. The impact of UH on mass 239 was monitored by analysis of a uranium sample in the same batch (Qiao et al., 2010).

A subset of six samples was analyzed (without prior alpha spectra analysis) for ${ }^{239} \mathrm{Pu}$ and ${ }^{240} \mathrm{Pu}$ via isotope dilution with ${ }^{242} \mathrm{Pu}$ at the Element2 sector field-ICP-MS facility at the AWI. This instrument is equipped with a jet interface. Samples were run at low mass resolution, using an APEX-IR desolvation system in order to maximize ion transmission of the samples. Effects of uranium hydride formation and instrumental mass bias were monitored and it was made sure that these effects did not affect the results. The accuracy and external comparability of the results were confirmed by analyzing two reference materials (IAEA-385 Irish Sea sediment and IAEA-384 Fangataufa Lagoon sediment) alongside the samples.

The statistical errors from ICP-MS analysis are reported for the isotope ratios and for activity concentrations they are combined with sample mass determination and the spike activity (5\%) errors.

\subsection{Bulk organic geochemistry}

Sediment core GeoB17409 was analyzed for contents of total organic carbon (TOC) and its stable carbon isotope values $\left(\delta^{13} \mathrm{C}-\mathrm{TOC}\right)$ according to Schmidt et al. (2017). Briefly, determinations were performed using a ThermoFinnigan Flash 2000 elemental analyzer connected to a Delta V Plus isotope ratio mass spectrometer (EA-IRMS) at MARUM - Center for Marine Environmental Sciences, Bremen. The primary standardization was based on multiple injections of a $\mathrm{CO}_{2}$ reference gas standard $\left(\delta^{13} \mathrm{C}=35.52 \pm 0.1 \%\right.$ orelative to Vienna Pee Dee Belemnite $)$ calibrated against the international IAEA-CH-6 standard. Standard deviation for $\delta^{13} \mathrm{C}-\mathrm{TOC}$ values were below $0.1 \%$ o. Quantitative analysis of TOC was performed by linear correlation of different amounts of carbon of an internal lab standard and signal intensity recorded by EA-IRMS. 


\section{GeoB 17402}
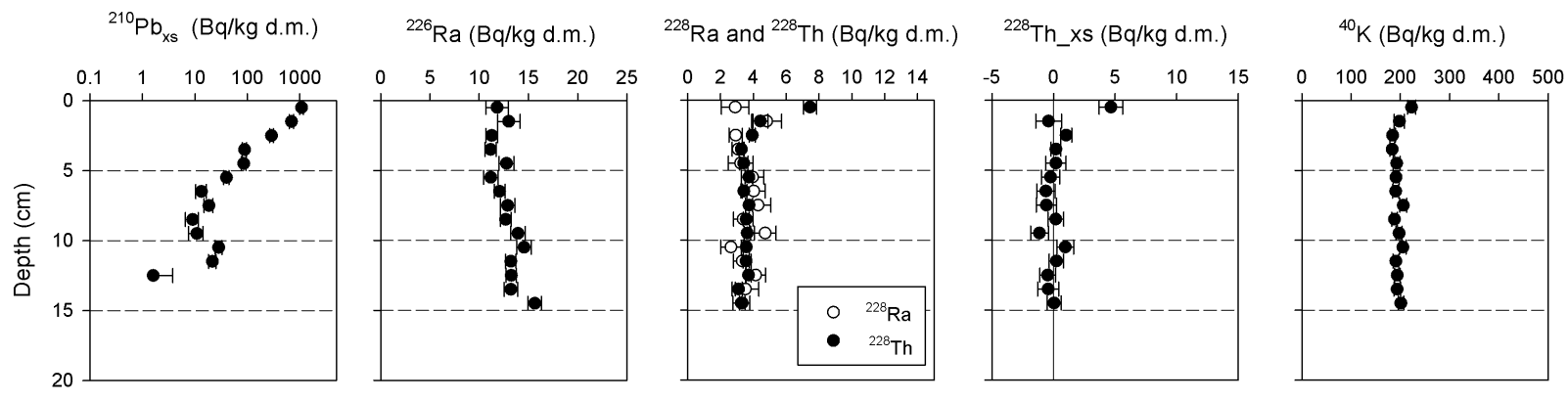

\section{GeoB 17409}
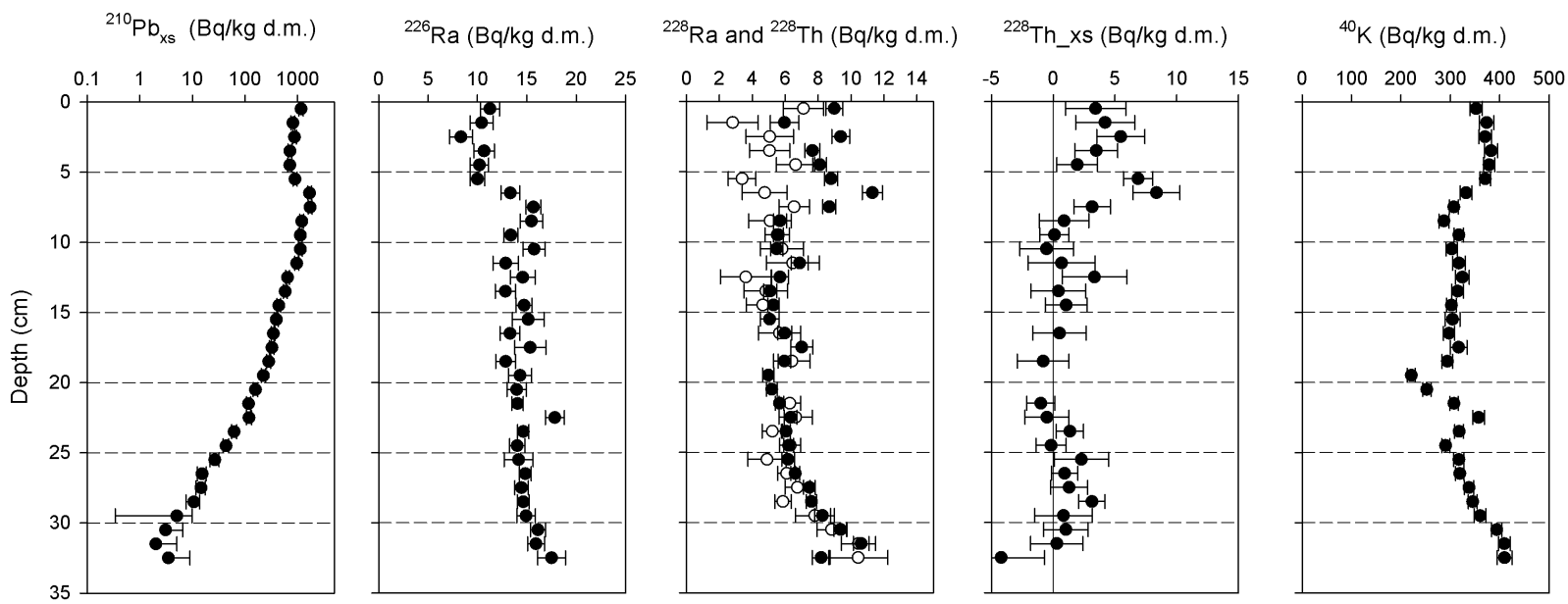

Figure 2: Depth profiles of natural radionuclides measured in sediment cores by gamma spectrometry. The error bars represent $1 \sigma$ combined counting and calibration uncertainties.

\section{Results}

\subsection{Natural radionuclides}

Excess ${ }^{210} \mathrm{~Pb}$ was found in the upper $12 \mathrm{~cm}$ of the core GeoB17402 with the topmost sample reaching an activity of over $1,100 \mathrm{~Bq} \cdot \mathrm{kg}^{-1}$ (Fig. 2). The decrease of activity with depth was close to exponential. ${ }^{226} \mathrm{Ra}$ increased with depth slightly. The uppermost sample showed an excess of ${ }^{228} \mathrm{Th}$ over ${ }^{226} \mathrm{Ra}$.

In core GeoB17409, natural radionuclide depth profiles revealed a distinct difference between the upper $6 \mathrm{~cm}$ layer and the rest of the core. Excess ${ }^{210} \mathrm{~Pb}$ was present in the entire length $(33 \mathrm{~cm})$. Its activity concentrations varied between 700 and $1,200 \mathrm{~Bq} \cdot \mathrm{kg}^{-1}$ in the top layer and below that, they decreased almost exponentially to values close to $0 .{ }^{226} \mathrm{Ra}$ activity concentrations were around $10 \mathrm{~Bq} \cdot \mathrm{kg}^{-1}$ in the top $6 \mathrm{~cm}$ layer and rose distinctly in greater depth to about $15 \mathrm{~Bq} \cdot \mathrm{kg}^{-1}$. In Th-series, a remarkable disequilibrium was present within the top $6 \mathrm{~cm}$. Additionally, the ${ }^{228} \mathrm{Th}_{x s}$ was not only present in the top $6 \mathrm{~cm}$, but down to $8 \mathrm{~cm}$. Both Th-series isotopes, ${ }^{228} \mathrm{Ra}$ and ${ }^{228} \mathrm{Th}$, increased at a depth of about $30 \mathrm{~cm}$, in a similar way ${ }^{40} \mathrm{~K}$ did. ${ }^{40} \mathrm{~K}$ additionally showed increased values in the top $6 \mathrm{~cm}$. Generally, both Th-series isotopes and ${ }^{40} \mathrm{~K}$ activities were significantly higher in GeoB17409 core in comparison to GeoB17402.

\subsection{Anthropogenic radionuclides}

Anthropogenic ${ }^{241} \mathrm{Am}$ and ${ }^{137} \mathrm{Cs}$ were found in the core GeoB17402 in the upper $12 \mathrm{~cm}$ (Fig. 3), similarly to excess ${ }^{210} \mathrm{~Pb}$. ${ }^{241} \mathrm{Am}$ was present in almost all layers and concentrations decreased from $2 \mathrm{~Bq} \cdot \mathrm{kg}^{-1}$ at the top to 0.2 $\mathrm{Bq} \cdot \mathrm{kg}^{-1}$. The typical decision threshold was $0.35 \mathrm{~Bq} \cdot \mathrm{kg}^{-1}$. ${ }^{137} \mathrm{Cs}$ was detected in low concentrations of $0.2-0.5$ 


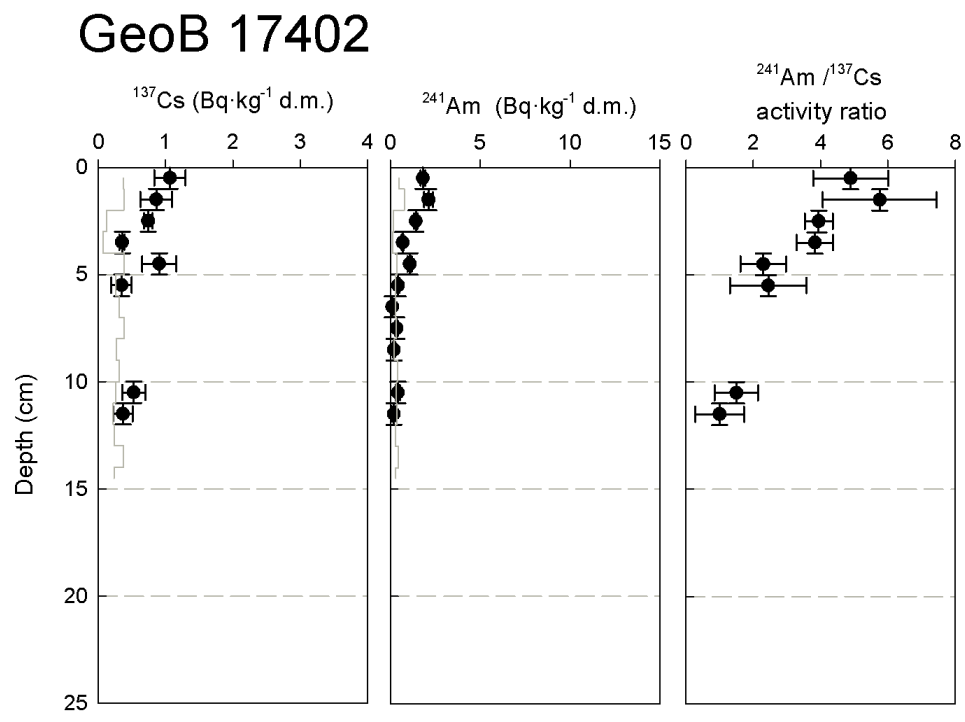

GeoB 17409

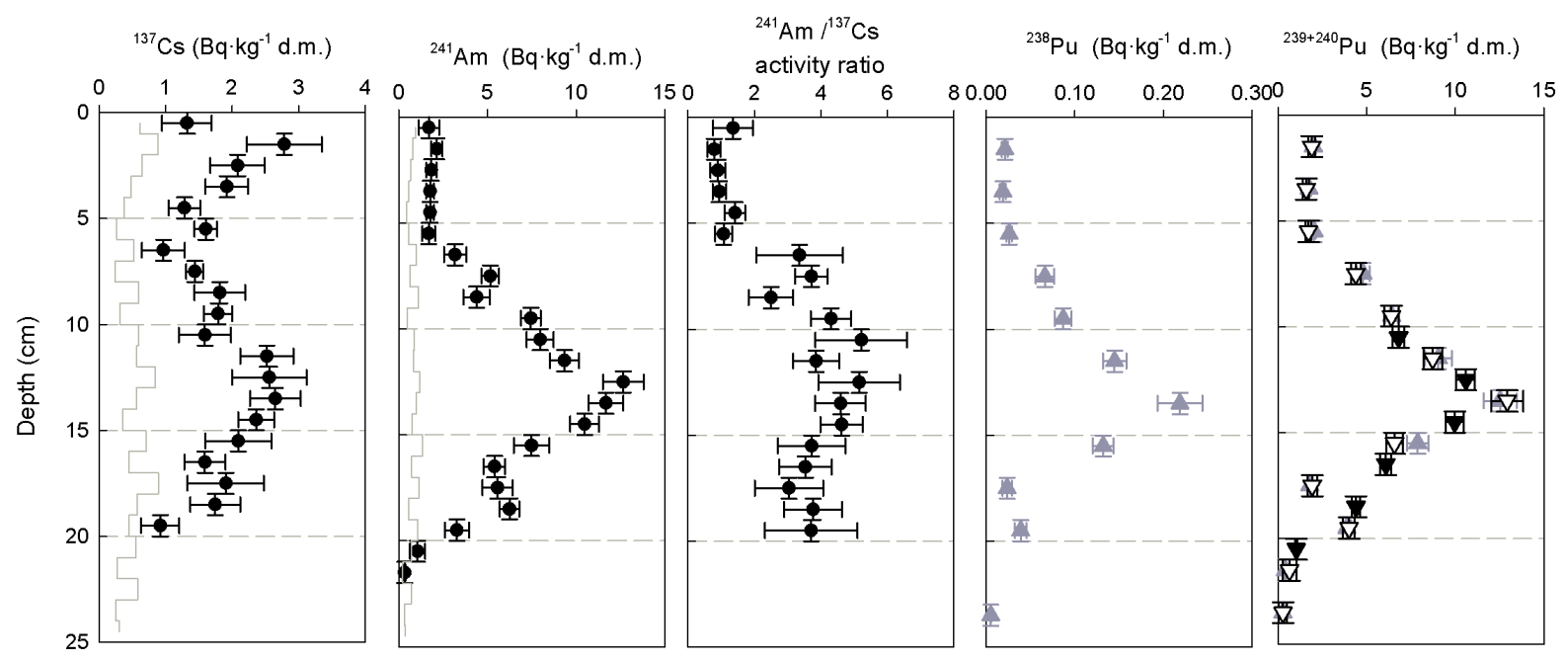

Figure 3: Depth profiles of artificial radionuclides measured in sediment cores. Gamma spectrometry data are plotted in full circles with decision threshold marked by a line, alpha spectrometry data in grey triangles. Plutonium isotope values plotted in full triangles were measured in NUTECH, empty triangles in AWI. The horizontal error bars represent $1 \sigma$ combined counting and calibration uncertainties, the vertical error bars the sampling layer thickness. 
$\mathrm{Bq} \cdot \mathrm{kg}^{-1}$, which was close to the average decision threshold of $0.3 \mathrm{~Bq} \cdot \mathrm{kg}^{-1} \cdot{ }^{241} \mathrm{Am} /{ }^{137} \mathrm{Cs}$ ratios were decreasing from close to 6 at the surface to 1 at $12 \mathrm{~cm}$ depth. Plutonium isotopes were not analyzed in this core (see Discussion in section 4.2).

Very high ${ }^{241} \mathrm{Am}$ concentrations were found in the core GeoB17409, with the maximum reaching over $12 \mathrm{~Bq} \cdot \mathrm{kg}^{-1}$ in the 12-13 cm depth increment. In low activities it was detected down to a depth of $22 \mathrm{~cm}$. Activities of ${ }^{137} \mathrm{Cs}$ were generally lower (up to $2.8 \mathrm{~Bq} \cdot \mathrm{kg}^{-1}$ ), reaching a less prominent maximum at approximately the same depth. An increased activity was additionally found in the $1-2 \mathrm{~cm}$ depth interval. ${ }^{241} \mathrm{Am} /{ }^{137} \mathrm{Cs}$ ratios were close to 1 in the upper $6 \mathrm{~cm}$ and significantly higher (2.5-5.2) in the rest of the core.

${ }^{239+240} \mathrm{Pu}$ and ${ }^{238} \mathrm{Pu}$ activity concentrations closely followed those of ${ }^{241} \mathrm{Am}$ with distinct subsurface maxima of over $12 \mathrm{~Bq} \cdot \mathrm{kg}^{-1}$ and $0.22 \mathrm{~Bq} \cdot \mathrm{kg}^{-1}$, respectively, at $13-14 \mathrm{~cm}$ depth. The ${ }^{239+240} \mathrm{Pu}$ data plotted in Fig. 3 were acquired by four different systems: two alpha spectrometers (AWI and IUP), as well as two ICP-MS systems (NUTECH and AWI). The agreement of repeated measurements, as well as overall consistency of data, are indications of solid instrument calibration and intercomparability of the results.

\section{Discussion}

\subsection{Typhoon-related layer}

Both natural radionuclides depth profiles in sediment core GeoB17409 showed a distinct change in the sedimentation of the topmost $6 \mathrm{~cm}$ thick layer, including the flattening of excess ${ }^{210} \mathrm{~Pb}$ decay, a sharp increase in ${ }^{40} \mathrm{~K}$ and a sharp decrease in ${ }^{226} \mathrm{Ra}$. Also this layer showed a disequilibrium between ${ }^{228} \mathrm{Ra}$ and ${ }^{228} \mathrm{Th}$, which can be interpreted as a relatively young feature - the decay of excess ${ }^{228} \mathrm{Th}$ happens with the half-life of 1.9 years. ${ }^{228} \mathrm{Th}_{x s}$ is additionally present in the depths of 6-8 cm, which again is a sign of a very young sediment. ${ }^{228} \mathrm{Th}_{x s}$ was previously reported in top layers of sediments due to its high particle affinity and preferential scavenging (Pittauerová et al., 2014). A remarkable change in artificial radionuclides can be observed in the same $6 \mathrm{~cm}$ top layer. It is characterized by low concentrations of $\mathrm{Am}$ and $\mathrm{Pu}$, as well as drop in ${ }^{241} \mathrm{Am} /{ }^{137} \mathrm{Cs}$ ratio. A lower ratio is typical for soils and coastal sediments, as opposed to deep sea environments.

The event responsible for the observed layer of young material is considered to be the typhoon Bopha, unusually southerly and at the same time the strongest tropical cyclone to hit Mindanao in recorded history. The typhoon reached Mindanao west coast in December 2012, only 6 months before the sediment coring. The effects on land included Cateel river flooding, destruction of coastal urban areas, infrastructure, agricultural land, and deforesting vast areas (UNEP/OCHA JEU, 2013; Alojado \& Padua, 2015). Previously, the effects of tropical storms on marine sediment deposition were for example observed off the coast of Fuji after Typhoon Saola in 2012 (Li et al., 2015). To further support the hypothesis of typhoon-related origin of the top layer, in Fig. 4A total organic carbon (TOC) and stable isotopic composition of TOC $\left(\delta^{13} \mathrm{C}\right.$-TOC) are presented. The characteristic marine plankton $\delta^{13} \mathrm{C}$-TOC values range from $-20 \%$ to $-22 \%$, whereas terrestrial organic matter $-26 \%$ to $-32 \%$. In core GeoB 17409 a mixture of both components is present; the more depleted $\delta^{13} \mathrm{C}$-TOC values in the top $6 \mathrm{~cm}$ point to a more terrestrial origin (Fig. 4B). The typhoon reportedly caused Cateel river flooding, which likely increased the terrestrial (soil) organic matter export for the period of its duration. This material could have been exported to the sampling site GeoB17409 located $13 \mathrm{~km}$ in front of the delta. It is also possible that the GeoB17409 site received more resuspended material from the shelf as an aftermath of the flooding. The ${ }^{228} \mathrm{Th}$ might have been very effectively scavenged from the water column by abundant particles, which explains the observed activities in excess of ${ }^{228} \mathrm{Ra}$.

\subsection{Sediment dating}

The activity of ${ }^{210} \mathrm{~Pb}_{x s}$ in core GeoB 17402 decreases exponentially towards 0 . When assuming a constant accumulation rate and constant flux, the exponential fit to the data provides an accumulation rate of $0.052 \pm 0.002 \mathrm{~g} \cdot \mathrm{cm}^{-2} \mathrm{yr}^{-1}$. With this rate of sediment accumulation, the appearance of anthropogenic radionuclides related to 1950's to 1960's fallout should be observed in the 3-5 cm subsurface layer. The fact, that the anthropogenic radionuclides activities maximum occurs in the surface layer, and that they reach far deeper in the profile than $5 \mathrm{~cm}$, indicates, that the leading process controlling their distribution might be mixing, rather than sedimentation. Such cores, with low sediment accumulation and potentially deep mixing, are not suitable for providing high resolution information of anthropogenic 


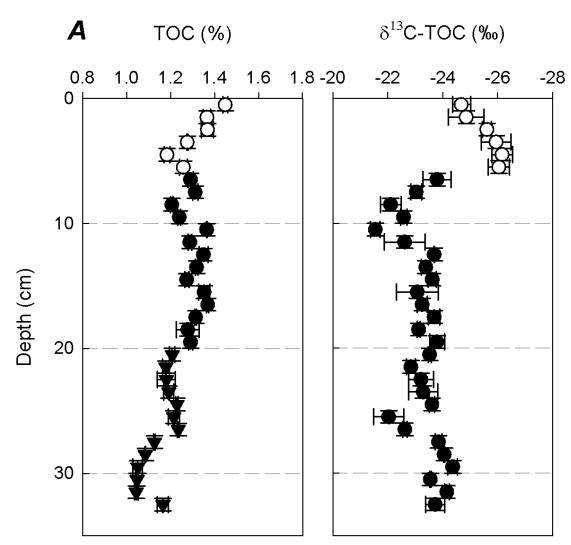

B

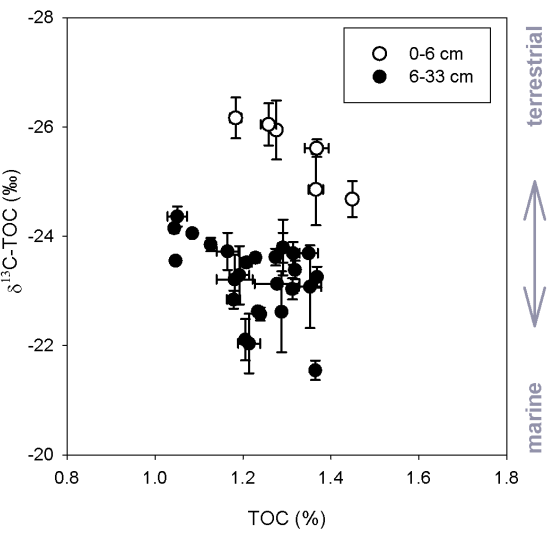

Figure 4: Organic geochemical data in core GeoB17409. The error bars reflect standard deviations from repeated measurements.

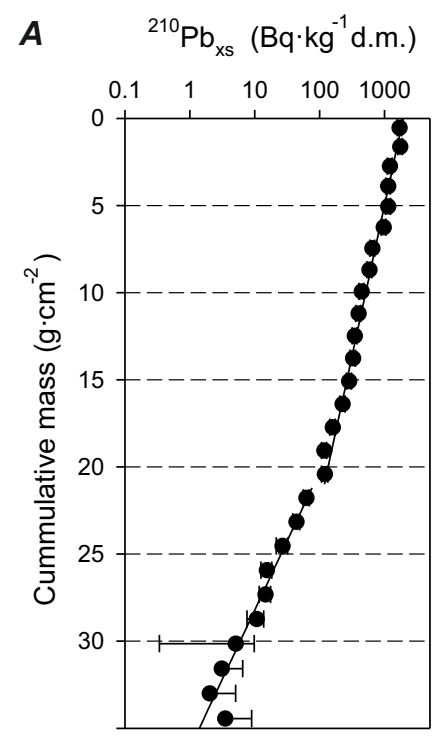

B ${ }^{239+240} \mathrm{Pu}\left(\mathrm{Bq} \cdot \mathrm{kg}^{-1} \mathrm{~d} . \mathrm{m}\right.$.)

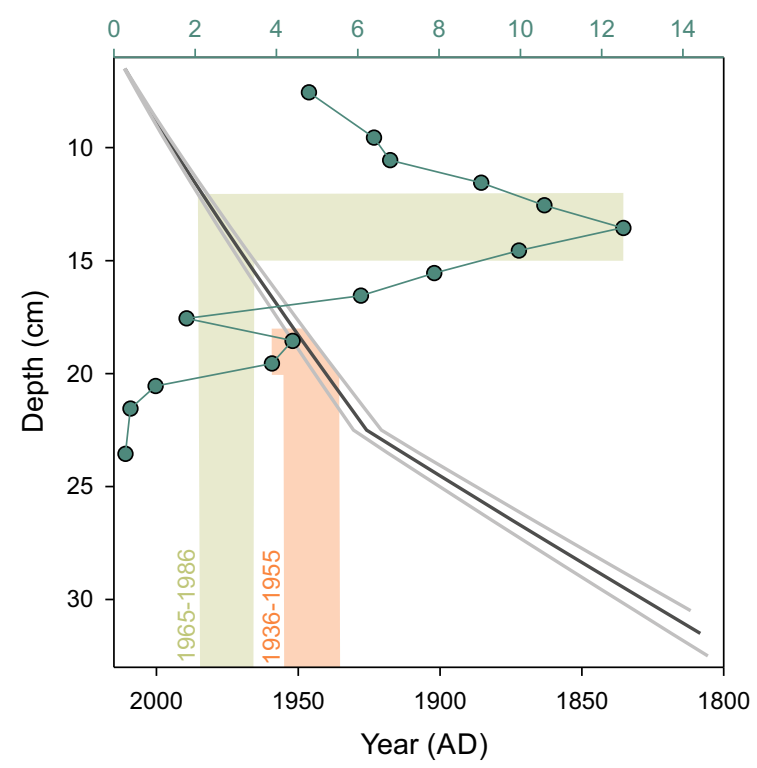

Figure 5: A: The ${ }^{210} \mathrm{~Pb}_{x s}$ depth profile in GeoB17409 used for the age model: piecewise CF-CS. The top typhoon-related $6 \mathrm{~cm}$ layer was excluded from the model. B: Depth vs age relationship, grey lines represent $1 \sigma$ uncertainty from the CF-CS model. On the secondary axis the activity of ${ }^{239+240} \mathrm{Pu}$ is plotted. Age refers to ${ }^{210} \mathrm{~Pb}_{x s}$ derived values. The timing of the ${ }^{239+240} \mathrm{Pu}$ onset and maximum are highlighted. 


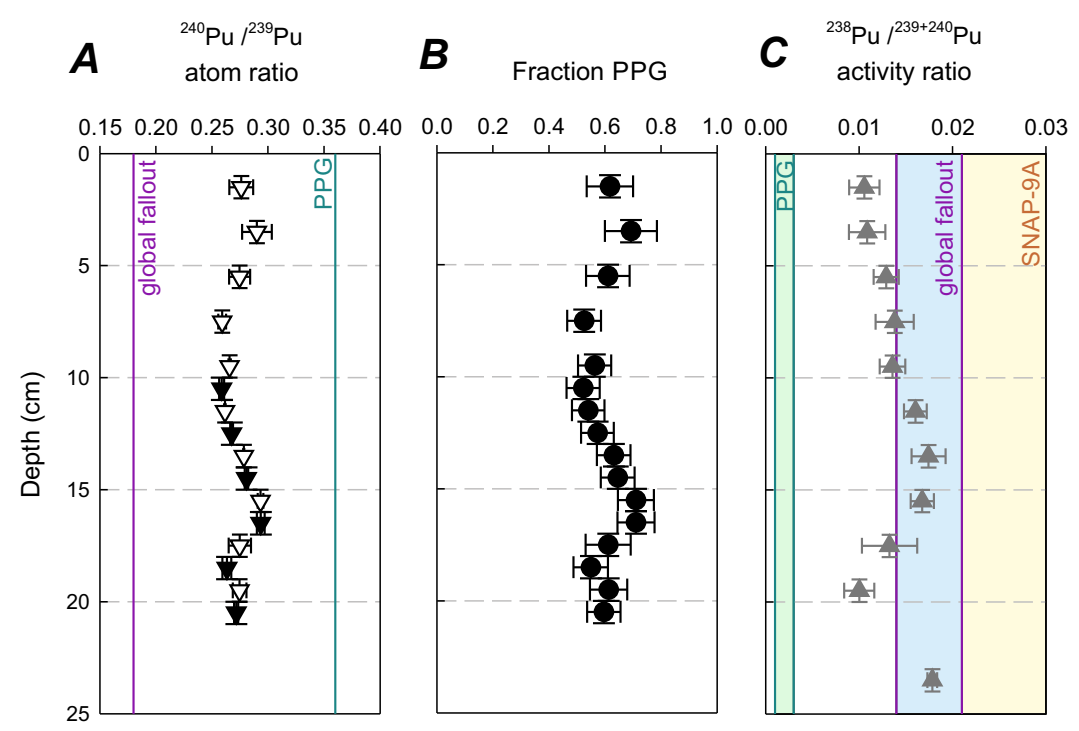

Figure 6: $(\mathrm{A}, \mathrm{C})$ Activity and atom ratios of plutonium isotopes. Alpha spectrometry data in grey triangles, ${ }^{240} \mathrm{Pu} /{ }^{239} \mathrm{Pu}$ atom ratios in full triangles were measured in NUTECH, empty triangles in AWI. The horizontal error bars represent $1 \sigma$ statistical error, the vertical error bars the sampling layer thickness. (B) Fractions of PPG plutonium calculated from two end-member model. (C) The coloured areas stand for the global fallout ratio of 0.014-0.021 (Lindahl et al., 2010), Castle Bravo (marked PPG) ratio of 0.001-0.003 (Komura et al., 1984), and post-SNAP-9A value for the northern hemisphere of 0.021-0.031 (Lindahl et al., 2010). All values were corrected to 2013.

radionuclide deposition. The laborious and costly analyses of plutonium isotopes were therefore not performed on this core.

For reasons mentioned in Section 4.1, in the GeoB17409 core the top $6 \mathrm{~cm}$ were excluded from the age model. Thereby the sediment just below the topmost $6 \mathrm{~cm}$ layer was considered to have been deposited just before the Typhoon Bopha (December 2012), as it contained ${ }^{228} \mathrm{Th}_{x s}$. A piecewise Constant Flux-Constant Sedimentation rate (CF-CS) model (Appleby, 2001) on ${ }^{210} \mathrm{~Pb}_{x s}$ data was used for sections of 6-22 $\mathrm{cm}$ and $22-33 \mathrm{~cm}$, which showed slightly different slopes in the logarithmic scale (Fig. 5A). The accumulation rates were $0.233 \pm 0.013$ and $0.107 \pm 0.005$ $\mathrm{g} \cdot \mathrm{cm}^{-2} \mathrm{yr}^{-1}$, respectively. The age model extends to $1795 \pm 11$ at the base of the core. The change is the ${ }^{210} \mathrm{~Pb}_{x s}$ activity decrease below $20 \mathrm{~cm}$ depth is accompanied by a gradual increase of Th-series and ${ }^{40} \mathrm{~K}$ towards greater depth (Fig. 2). At the same time, TOC content is lower in the deeper layers (Fig. 4A). This could be an indication for a greater clay mineral proportion, but the processes leading to that cannot be reconstructed based on available data.

The validity of the model can be verified by the anthropogenic radionuclides (Fig. 5B). The first significant appearance of ${ }^{239+240} \mathrm{Pu}$ at the depth of $18-20 \mathrm{~cm}$ is according to this age model dated between 1936-1955. While the centre of this lower peak is dated older that expected, the upper time limit is plausible, because the first expected arrival of a plutonium signal is related to the 1952 Ivy Mike thermonuclear test. The traces of Am and Pu observed below 20 $\mathrm{cm}$ depth can be caused by bioturbation or by cross-contamination during sampling. The maximum of plutonium in the depth profile is located between 12-15 cm, which according to the CF-CS model covers time between 1965-1986. This is somewhat later than it would be expected from maximum global fallout in 1963.

\subsection{Sources of plutonium}

The isotopic composition of plutonium isotopes in the studied sediment can provide a fingerprint of its origin. The ${ }^{240} \mathrm{Pu} /{ }^{239} \mathrm{Pu}$ atom ratios in the core GeoB17409 vary from 0.26 to 0.29 (Fig. 6A), and therefore significantly exceed the characteristic global fallout ratio of $0.176 \pm 0.008$, obtained from 15 soil samples collected between $30^{\circ} \mathrm{N}$ and $30^{\circ} \mathrm{S}$ (Kelley et al., 1999). ${ }^{240} \mathrm{Pu} /{ }^{239} \mathrm{Pu}$ variability in the depth profile is low, the maximum values exceeding 0.29 appear in the depth of $15-17 \mathrm{~cm}$.

The ${ }^{240} \mathrm{Pu} /{ }^{239} \mathrm{Pu}$ atom ratios of tests at the PPG were typically higher than in integrated global fallout. Froehlich et al. (2016) documented high variation of isotopic ratios of different tests conducted at Enewetak Atoll over the time span of 1951-1963 based on a high resolution coral record from the atoll lagoon. While the ratio related to the 1952 
Ivy Mike test was found to be $0.379 \pm 0.038$, close to $0.363 \pm 0.004$ reported by (Diamond et al., 1960) in the airborne and condensed debris, the coral record also showed high variability in isotopic composition of the local fallout. During the period 1952-1955 the ratios decreased from $0.424 \pm 0.026$ to $0.234 \pm 0.016$. In 1956 and 1958 the values dropped to $\sim 0.17$ and $\sim 0.08$.

The largest thermonuclear test conducted at the PPG, Castle Bravo, at the Bikini Atoll in 1954 was responsible for large-scale contamination not only of Bikini, but also of Rongelap and Utirik atolls and the Japanese fishing vessel, Daigo Fukuryu Maru. The Bikini Atoll soil ${ }^{240} \mathrm{Pu} /{ }^{239} \mathrm{Pu}$ atom ratio was found to be $0.34 \pm 0.05$ and the value associated to the Castle Bravo test fallout at the Daigo Fukuryu Maru 0.32 \pm 0.03 (Komura et al., 1984).

Therefore, the observed high ratios point to a high portion of PPG-derived plutonium. Assuming that the plutonium activity in the core is a mixture of global and PPG fallout, the contributions of global and PPG derived plutonium can be resolved from the measured ${ }^{240} \mathrm{Pu} /{ }^{239} \mathrm{Pu}$ atom ratios $R_{M}$ using a two end-member mixing model (Krey, 1976):

$$
A=\frac{P u_{P P G}}{P u_{G l o}}=\frac{\left(R_{G l o}-R_{M}\right)\left(1+3.674 \cdot R_{P P G}\right)}{\left(R_{M}-R_{P P G}\right)\left(1+3.674 \cdot R_{G l o}\right)},
$$

where 3.674 is a factor for conversion between atom and activity ratios of ${ }^{240} \mathrm{Pu} /{ }^{239} \mathrm{Pu}$. The portions of activity due to PPG from total Pu activities are then calculated as:

$$
\frac{P u_{P P G}}{P u_{P P G}+P u_{G l o}}=\frac{A}{1+A} .
$$

Although it is acknowledged that PPG fallout varies with time, for the minimum PPG contribution estimate the relatively high and frequently cited PPG end-member value of $0.36 \pm 0.02$ can by applied alongside with the global fallout end-member of $0.18 \pm 0.01$. According to this calculation, on average $60 \%$ of plutonium in the studied core originates from the PPG (Fig. 6B).

The ${ }^{238} \mathrm{Pu} /{ }^{239+240} \mathrm{Pu}$ activity ratios in the sediment core GeoB17409 (Fig. 6C) were found in the range of $0.01-$

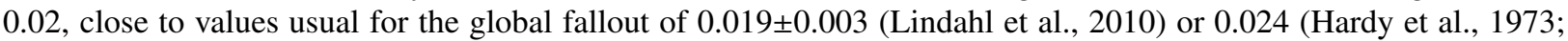
Harley, 1980). This suggests that no significant fallout from the SNAP-9A satellite is present at the sampling site. SNAP-9A was responsible for the global fallout ${ }^{238} \mathrm{Pu} /{ }^{239+240} \mathrm{Pu}$ activity ratio increase to $0.029 \pm 0.005$ on average in the Northern hemisphere and to $0.14 \pm 0.04$ in the Southern Hemisphere (Lindahl et al., 2010). High post-SNAP-9A ${ }^{238} \mathrm{Pu} /{ }^{239+240} \mathrm{Pu}$ values (up to 0.5 ) for example were reported from a New Zealand lake sediment (Hancock et al., 2011). On the contrary, the PPG related ${ }^{238} \mathrm{Pu} /{ }^{239+240} \mathrm{Pu}$ activity ratios are lower than in global fallout. Komura et al. (1984) reported a value of 0.004 in Bikini soil and 0.001 in a fishing gear from the Daigo Fukuryu Maru boat affected by the 1954 Castle Bravo fallout. Because the GeoB17409 values are in the lower range or below the global fallout values, a contribution from the PPG is also plausible. However, no correlation of ${ }^{238} \mathrm{Pu} /{ }^{239+240} \mathrm{Pu}$ activity ratios with ${ }^{240} \mathrm{Pu} /{ }^{239} \mathrm{Pu}$ atom ratios was observed.

\subsection{Inventories}

The particle reactive radionuclide inventories found in our study area are exceptionally high (Table 2). They were calculated as a sum of measured values of activity concentration $C_{i}$ in the sediment core as:

$$
I=\sum C_{i} \cdot z_{i} \cdot \rho_{i}
$$

where $z_{i}$ is the thickness and $\rho_{i}$ the dry bulk density of the $i^{\text {th }}$ core slice.

The ${ }^{210} \mathrm{~Pb}_{x s}$ inventory of $23,900 \pm 1,000$ and $180,700 \pm 3,700 \mathrm{~Bq} \cdot \mathrm{m}^{-2}$ exceeds values expected from the direct atmosphere deposition and production from ${ }^{226} \mathrm{Ra}$ in water column. The expected atmospheric deposition in the area is assumed to be similar to $180 \mathrm{~Bq} \cdot \mathrm{m}^{-2} \mathrm{yr}^{-1}$ reported by Lee et al. (2004), based on long-term observation in northern Taiwan ( $\mathrm{Su}$ et al., 2003). The water column produced ${ }^{210} \mathrm{~Pb}$ is relatively low compared to this value, given the expected ${ }^{226} \mathrm{Ra}$ activity of about $1 \mathrm{~Bq} \cdot \mathrm{m}^{-3}$ (Nozaki et al., 1990) integrated over $500 \mathrm{~m}$ depth, accounting for 15 . $\mathrm{m}^{-2} \mathrm{yr}^{-1}$. When continuously deposited in the sediment, this flux would support sediment inventories of $6,200 \mathrm{~Bq}$. $\mathrm{m}^{-2}$.

The high inventories of particle reactive radionuclides, strongly resembling the situation observed in the Okinawa Trough (Lee et al., 2004), point to conditions of boundary scavenging. The situation of radionuclide rich water masses being transported with NEC from the open Pacific, poor on nutrient and particles, changes upon arrival to 


\begin{tabular}{|c|c|c|c|c|c|c|}
\hline & \multirow[b]{2}{*}{ Depth (m) } & \multicolumn{4}{|c|}{ Inventory $\left(\mathrm{Bq} \cdot \mathrm{m}^{-2}\right)$} & \multirow[b]{2}{*}{ Reference (core) } \\
\hline & & ${ }^{210} \mathrm{~Pb}_{x s}$ & ${ }^{137} \mathrm{Cs}^{*}$ & $239+240 \mathrm{Pu}$ & ${ }^{241} \mathrm{Am}^{* *}$ & \\
\hline Philippine Sea & 506 & $23,900 \pm 1,000$ & $>68 \pm 7$ & n.d. & $>231 \pm 1$ & This study (GeoB17402) \\
\hline Philippine Sea & 553 & $180,700 \pm 3,700$ & $409 \pm 19$ & $1,218 \pm 11$ & $1,332 \pm 37$ & This study (GeoB17409) \\
\hline Lombok Basin & 1284 & $61,300 \pm 1,700$ & $84 \pm 15$ & $219 \pm 3$ & $314 \pm 18$ & Pittauer et al. 2017 (GeoB10065) \\
\hline Okinawa Trough & 1284 & $120,833 \pm 3,333$ & $228 \pm 5$ & $407 \pm 2$ & n.d. & Lee et al. $2004(679-7 a)$ \\
\hline South China Sea & 46 & $17,300 \pm 500$ & $580 \pm 40$ & $366 \pm 3$ & n.d. & Wu et al. 2014 (A8) \\
\hline Sagami Bay & 1329 & n.d. & 569 & 434 & n.d. & Zheng \& Yamada 2004; Yamada \& Nagaya 2000 (KT-91-03-8 ) \\
\hline $\begin{array}{l}\text { Philippine Sea } \\
\text { latitude } 0-10^{\circ} \mathrm{N}\end{array}$ & & 6,200 & 410 & 15 & $10^{* * * *}$ & $\begin{array}{l}\text { Lee et al. 2004; Nozaki et al. } 1990 \\
\text { UNSCEAR } 2000\end{array}$ \\
\hline
\end{tabular}

Table 2: Radionuclide inventories measured at the study sites. n.d. stands for not determined.

the continental margin off Philippines. Here higher primary production and abundance of continental particulate matter lead to rapid removal of particle reactive radionuclides and to their incorporation into sediment. This supports inventories an order of magnitude above those expected from local deposition. ${ }^{241} \mathrm{Am} /{ }^{137} \mathrm{Cs}$, as well as ${ }^{241} \mathrm{Am} /{ }^{10} \mathrm{~Pb}_{x s}$ and ${ }^{137} \mathrm{Cs} /{ }^{210} \mathrm{~Pb}_{x s}$ ratios, are very similar at both study sites. Comparable boundary scavenging processes take place, however the absolute inventories are significantly higher at the GeoB17409 site, which can be caused by local focusing and possibly transport from the shelf.

\subsection{Regional context}

Several previous studies resolved the temporal variability of anthropogenic radionuclide accumulation to sediments in nortwest Pacific and its marginal seas, to which we compare the presented data from the Philippine Sea.

Lee et al. (2004) reported high plutonium inventories, originating for a great part from the PPG in deep sea sediment cores from the southern Okinawa Trough off northeastern Taiwan. A sediment core (679-7a), representative for several cores collected at the study site, was compared to our data. A shallow sediment core (A8) from the South China Sea off the Pearl River estuary was analyzed within a study of Wu et al. (2014). It was shown that a substantial portion of the plutonium inventory (minimum of 60\%) originates from the PPG. Further northwest along the Kuroshio Current, Zheng \& Yamada (2004) reported data from a deep sea Sagami Bay sediment core (KT-91-03-8). This core does not provide explicit chronology using independent chronometers, but for the purposes of comparison within this study, the age was extrapolated between the 1963 fallout maximum and core top (sampling date in 1991). Here also a minimum of $44 \%$ plutonium arrived from the PPG. Finally, a deep sea sediment core (GeoB10065), taken in the Lombok Basin in the Indonesian archipelago, represents a record of continuous transport of PPG derived plutonium through the Indonesian Throughflow (Pittauer et al., 2017) towards the Indian Ocean.

Along the time scale, the records of ${ }^{239+240} \mathrm{Pu}$ activity in the cores are plotted together from all above mentioned sites (Fig. 7A), as well as ${ }^{240} \mathrm{Pu} /{ }^{239} \mathrm{Pu}$ atom ratios (Fig. 7B). The time axis is derived from the ${ }^{210} \mathrm{~Pb}$ models with exception of the Sagami Bay. It is important to mention, that some of the differences between the individual records can, and likely will be, caused by uncertainties of the age models. Furthermore, apart from sedimentation, mixing might likely play a role in depth distribution in sediment profiles. In some of the records, including the one from the present study, plutonium appears in the sediment dated earlier than 1945, which is not plausible, and can likely be assigned to some degree of post-depositional mixing. In the Lombok Basin, this early onset is at least partially an artefact related to a low resolution of core slicing in the deeper section $(5 \mathrm{~cm}$ intervals).

Furthemore, the timing of plutonium maxima differs significantly between the records. An early maximum can be observed in the South China Sea. In shallow, particle rich shelves, the residence times of plutonium would be comparatively very short; accordingly, plutonium is rapidly stripped off the water column shortly after arrival. In Sagami Bay plutonium maximum is present in early 1960's, however this is a circular argument, inasmuch as this maximum was used as a chronomarker for year 1963 to build an age model of the core. Around 1965, the maximum was recorded in Southern Okinawa Trough. The latest maxima were recorded in Lombok Basin (early 1970's) and Philippine Sea (mid-1970's, this study). Besides aforementioned possible artefacts, the reasons for differences in the timing of maxima might be spatial differences in plutonium residence times, which in turn would be a function of water depth and availability of particles for plutonium scavenging. Additionally, plutonium may reach the slope by delayed transport from the shelf. 

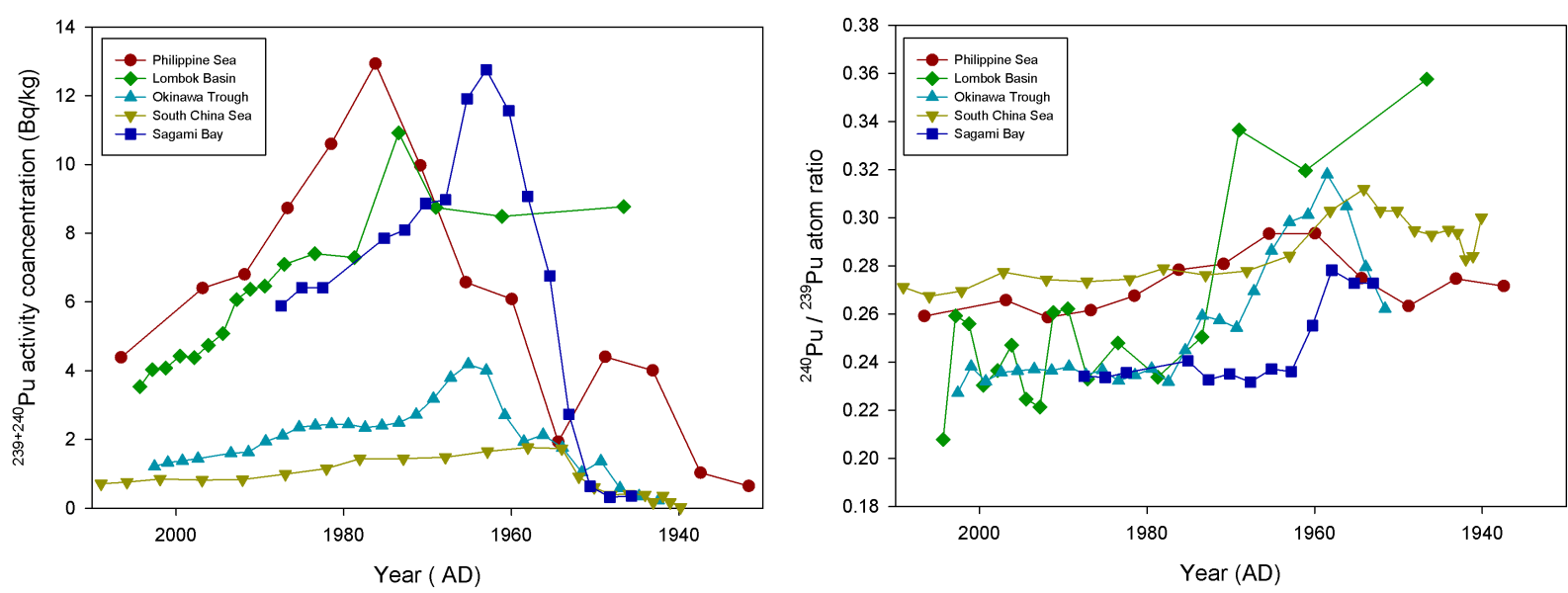

Figure 7: Plutonium activities and atom ratios observed in this study (Philippine Sea), compared to previous studies in Lombok basin (Pittauer et al., 2017), Okinawa Trough (Lee et al., 2004), South China Sea (Wu et al., 2014) and Sagami Bay (Zheng \& Yamada, 2004).

Generally, maxima of ${ }^{240} \mathrm{Pu} /{ }^{239} \mathrm{Pu}$ appear early in all compared records, followed by certain degree of decrease. High values (around 0.30) connected to high yield PPG tests in 1952-1954 precede the maximum activities of plutonium in all cores. In some studies, including Philippine Sea, South China Sea, and Okinawa Trough, the ${ }^{240} \mathrm{Pu} /{ }^{239} \mathrm{Pu}$ maxima occur only after certain interval with lower values. This can be a signature of earlier low yield PPG tests, between 1946 and 1951. Plutonium from them was recorded in banded corals from Guam island, located about 2,000 $\mathrm{km}$ west of PPG along the pathway of NEC (Lindahl et al., 2011). The concentrations were two orders of magnitude lower than those recorded in an aftermath of the thermonuclear tests. This proportion however might not be applicable to sediment deposits. Corals can take up plutonium only from the upper several meters of water column, as opposed to sediments. The residence time of plutonium in surface water is relatively short; along the NEC it was estimated to be about 8 years (Hirose et al., 2006). During particle scavenging to sediments the activity is integrated over deeper sections of the water column. This effect might also explain another remarkable difference between coral and sediment records of plutonium deposition: the activity in coral bands decreases exponentially after cessation of atmospheric testing, which is not reflected in a similar way in any of the sediment profiles.

\section{Conclusions}

Our study provides a new insight in the depositional history of anthropogenic radionuclides in the Pacific western boundary south of the North Equatorial Current bifurcation, along the pathway of the southward Mindanao Current. Sediments from the continental slope off Mindanao provide a high resolution record of the Anthropocene. One of the sediment cores revealed a layer of rapid sedimentation, which based on distinct radionuclide signatures, along with organic matter stable isotopes, appears to be material of more terrestrial origin related to the 2012 typhoon Bopha.

The studied site contains inventories of particle reactive radionuclides, including plutonium and americium, an order of magnitude higher than expected from direct deposition. As possible reasons for that we suggest effective boundary scavenging, and transport of material from the shelf, which is responsible for a delay between arrival of radionuclides in water column, and their deposition.

The isotopic composition of plutonium shows, that the minimum portion of plutonium originating from the PPG at the study site is $60 \%$. This implies, that plutonium is transported southward with the Mindanao Current in a comparable way to the way by which it is known to be transported northward with the Kuroshio Current. No signs of plutonium from the burned up SNAP-9A satellite were detectable. 


\section{Acknowledgment}

We thank the captain, crew, and scientific shipboard party of the German R/V SONNE SO-228 PABESIA expedition in 2013 (Bundesministerium für Bildung und Forschung project 03G0228A, EISPAC) for their support during sampling. Homa Ghasemifard (then IUP) is acknowledged for sample preparation for gamma-spectra analysis during the cruise, Volker Diekamp (MARUM) for sediment drying, Christina Gnade (MARUM) for sample preparation for organic carbon analysis, Jenny Wendt (MARUM) for the organic carbon analysis and Ingrid Stimac (AWI) for support with alpha analysis. Dominic Ransby's proofreading is highly appreciated. D.P. was funded through Deutsche Forschungsgemeinschaft Research Center/Cluster of Excellence The Ocean in the Earth System and she appreciates the support provided by GLOMAR, Bremen International Graduate School for Marine Sciences.

\section{References}

Alojado, D., \& Padua, D. M. V. (2015). Worst typhoons of the Philippines (1947-2014). Http://www.typhoon2000.ph/info.htm, accessed February 2017.

Appleby, P. G. (2001). Chronostratigraphic techniques in recent sediments. In W. M. Last, \& J. P. Smol (Eds.), Tracking Environmental Change Using Lake Sediments: Basin Analysis, Coring, and Chronological Techniques (pp. 171-203). Dordrecht: Springer Netherlands.

Corcho-Alvarado, J., Diaz-Asencio, M., Froidevaux, P., Bochud, F., Alonso-Hernández, C., \& Sanchez-Cabeza, J. (2014). Dating young Holocene coastal sediments in tropical regions: Use of fallout ${ }^{239,240} \mathrm{Pu}$ as alternative chronostratigraphic marker. Quaternary Geochronology, $22,1-10$.

Diamond, H., Fields, P. R., Stevens, C. S., Studier, M. H., Fried, S. M., Inghram, M. G., Hess, D. C., Pyle, G. L., Mech, J. F., Manning, W. M., Ghiorso, A., Thompson, S. G., Higgins, G. H., Seaborg, G. T., Browne, C. I., Smith, H. L., \& Spence, R. W. (1960). Heavy isotope abundances in Mike thermonuclear device. Physical Review, 119, 2000-2004.

Dong, W., Zheng, J., Guo, Q., Yamada, M., \& Pan, S. (2010). Characterization of plutonium in deep-sea sediments of the Sulu and South China Seas. Journal of Environmental Radioactivity, 101, 622-629.

Froehlich, M., Chan, W., Tims, S., Fallon, S., \& Fifield, L. (2016). Time-resolved record of ${ }^{236} \mathrm{U}$ and ${ }^{239,240} \mathrm{Pu}$ isotopes from a coral growing during the nuclear testing program at Enewetak Atoll (Marshall Islands). Journal of Environmental Radioactivity, 165, 197-05.

Hallstadius, L. (1984). A method for the electrodeposition of actinides. Nuclear Instruments and Methods in Physics Research, 223,266 - 267.

Hamilton, T. (2005). Linking legacies of the cold war to arrival of anthropogenic radionuclides in the oceans through the $20^{\text {th }}$ century. In H. D. Livingston (Ed.), Marine Radioactivity (pp. 23-78). Elsevier volume 6 of Radioactivity in the Environment.

Hancock, G. J., Leslie, C., Everett, S. E., Tims, S. G., Brunskill, G. J., \& Haese, R. (2011). Plutonium as a chronomarker in Australian and New Zealand sediments: a comparison with ${ }^{137}$ Cs. Journal of Environmental Radioactivity, 102, 919-929.

Hardy, E., Krey, P., \& Volchok, H. (1973). Global inventory and distribution of fallout plutonium. Nature, 241, 444-445.

Harley, J. H. (1980). Plutonium in the environment - a review. Journal of Radiation Research, 21, 83-104.

Hirose, K., Aoyama, M., Kim, C., Kim, C., \& Povinec, P. (2006). Plutonium isotopes in seawater of the North Pacific: Effects of close-in fallout. In P. Povinec, \& J. Sanchez-Cabeza (Eds.), Radionuclides in the EnvironmentInt. Conf. On Isotopes in Env. Studies (pp. 67-82). Elsevier volume 8 of Radioactivity in the Environment.

Hu, D., Wu, L., Cai, W., Gupta, A. S., Ganachaud, A., Qiu, B., Gordon, A. L., Lin, X., Chen, Z., Hu, S., Wang, G., Wang, Q., Sprintall, J., Qu, T., Kashino, Y., Wang, F., \& Kessler, W. S. (2015). Pacific western boundary currents and their roles in climate. Nature, 522, $299-308$.

Kelley, J., Bond, L., \& Beasley, T. (1999). Global distribution of Pu isotopes and ${ }^{237}$ Np. Science of the Total Environment, 237-238, 483-500.

Komura, K., Sakanoue, Masanobu, \& Yamamoto, M. (1984). Determination of ${ }^{240} \mathrm{Pu} /{ }^{239} \mathrm{Pu}$ Ratio in Environmental Samples Based on the Measurement of Lx/alpha-ray Activity Ratio. Health Physics, 46, 1213-1219.

Krey, P. W. (1967). Atmospheric burnup of a plutonium-238 generator. Science, 158, 769-771.

Krey, P. W. (1976). Remote plutonium contamination and total inventories from Rocky Flats. Health Physics, 30, $209-214$.

Lee, S.-Y., Huh, C.-A., Su, C.-C., \& You, C.-F. (2004). Sedimentation in the Southern Okinawa Trough: enhanced particle scavenging and teleconnection between the Equatorial Pacific and western Pacific margins. Deep Sea Research Part I: Oceanographic Research Papers, 51, 1769-1780.

León Vintró, L., Mitchell, P. I., Smith, K. J., Kershaw, P. J., \& Livingston, H. D. (2005). Transuranium nuclides in the world's oceans. In H. D. Livingston (Ed.), Marine Radioactivity (pp. 79-108). Elsevier volume 6 of Radioactivity in the Environment.

Li, Y., Li, H., Qiao, L., Xu, Y., Yin, X., \& He, J. (2015). Storm deposition layer on the Fujian coast generated by Typhoon Saola (2012). Scientific Reports, 5, 14904

Lindahl, P., Asami, R., Iryu, Y., Worsfold, P., Keith-Roach, M., \& Choi, M.-S. (2011). Sources of plutonium to the tropical Northwest Pacific Ocean (19431999) identified using a natural coral archive. Geochimica et Cosmochimica Acta, 75, $1346-1356$.

Lindahl, P., Lee, S.-H., Worsfold, P., \& Keith-Roach, M. (2010). Plutonium isotopes as tracers for ocean processes: A review. Marine Environmental Research, 69, 73-84.

Mohtadi, M., \& cruise participants (2013). Report and preliminary results of RV SONNE Cruise SO-228, Kaohsiung - Townsville (04.05.201323.06.2013), EISPAC-WESTWIND-SIODP. Expedition report 295 Fachbereich Geowissenschaften, Universität Bremen.

Nozaki, Y., Ikuta, N., \& Yashima, M. (1990). Unusually large ${ }^{210} \mathrm{~Pb}$ deficiencies relative to ${ }^{210} \mathrm{~Pb}$ in the Kuroshio Current of the East China and Philippine seas. Journal of Geophysical Research: Oceans, 95, 5321-5329.

Pittauer, D., Tims, S., Froehlich, M., Fifield, K., Wallner, A., McNeil, S., \& Fischer, H. W. (2017). Continuous transport of Pacific-derived anthropogenic radionuclides towards the Indian Ocean. Scientific Reports, 7, 44679

Pittauerová, D., Kirchner, G., Garbe-Schönberg, D., Herut, B., Nishri, A., \& Fischer, H. W. (2014). Radionuclides and recent sedimentation and mixing rates in Northern Gulf of Eilat/Aqaba, Red Sea. Journal of Marine Systems, 139, 1-8. 
Povinec, P. P., Livingston, H. D., Shima, S., Aoyama, M., Gastaud, J., Goroncy, I., Hirose, K., Huynh-Ngoc, L., Ikeuchi, Y., Ito, T., La Rosa, J., Wee Kwong, L. L., Lee, S.-H., Moriya, H., Mulsow, S., Oregioni, B., Pettersson, H., \& Togawa, O. (2003). IAEA97 expedition to the NW Pacific Ocean results of oceanographic and radionuclide investigations of the water column. Deep Sea Research Part II: Topical Studies in Oceanography, 50, $2607-2637$

Qiao, J., Hou, X., Roos, P., \& Miró, M. (2010). Rapid and simultaneous determination of neptunium and plutonium isotopes in environmental samples by extraction chromatography using sequential injection analysis and ICP-MS. Journal of Analytical Atomic Spectrometry, 25, 17691779 .

Qiao, J., Hou, X., Roos, P., \& Miró, M. (2011). High-throughput sequential injection method for simultaneous determination of plutonium and neptunium in environmental solids using macroporous anion-exchange chromatography, followed by inductively coupled plasma mass spectrometric detection. Analytical Chemistry, 83, 374-381.

Qu, T., \& Lukas, R. (2003). The bifurcation of the North Equatorial Current in the Pacific. Journal of Physical Oceanography, 33, 5-18.

Schlitzer, R. (2016). Ocean Data View. http://odv.awi.de.

Schmidt, F., Koch, B. P., Goldhammer, T., Elvert, M., Witt, M., Lin, Y. S., Wendt, J., Zabel, M., Heuer, V. B., \& Hinrichs, K. U. (2017). Unraveling signatures of biogeochemical processes and the depositional setting in the molecular composition of pore water DOM across different marine environments. Geochimica et Cosmochimica Acta, .

Schönau, M. C., Rudnick, D. L., Cerovecki, I., Gopalakrishnan, G., Cornuelle, B. D., McClean, J. L., \& Qiu, B. (2015). The Mindanao current: Mean structure and connectivity. Oceanography, 28.

Schwenk, T. (2017). Personal communication.

Steinke, S., Mohtadi, M., Prange, M., Varma, V., Pittauerova, D., \& Fischer, H. (2014). Mid- to late-holocene Australian-Indonesian summer monsoon variability. Quaternary Science Reviews, 93, 142-154.

Su, C.-C., Huh, C.-A., \& Lin, F.-J. (2003). Factors controlling atmospheric fluxes of ${ }^{7}$ Be and ${ }^{210}$ Pb in northern Taiwan. Geophysical Research Letters, 30.

Tims, S., Pan, S., Zhang, R., Fifield, L., Wang, Y., \& Gao, J. (2010). Plutonium AMS measurements in Yangtze River estuary sediment. Nuclear Instruments and Methods in Physics Research Section B: Beam Interactions with Materials and Atoms, $268,1155-1158$.

UNEP/OCHA JEU (2013). Environmental issues related to Bopha/Pablo typhoon Eastern Mindanao, Philippines. Technical Report UN Environment Programme / UN Office for the Coordination of Humanitarian Affairs Joint Environment Unit.

UNSCEAR (2000). Report to the General Assembly, with scientific annexes. Sources and effects of ionizing radiation. Volume 1: Sources. Annex C United Nations Scientific Committee on the Effects of Atomic Radiation New York.

Wang, J., Baskaran, M., Hou, X., Du, J., \& Zhang, J. (2017). Historical changes in ${ }^{239} \mathrm{Pu}$ and ${ }^{240} \mathrm{Pu}$ sources in sedimentary records in the East China Sea: Implications for provenance and transportation. Earth and Planetary Science Letters, 466, 32 - 42.

Wang, Z.-1., \& Yamada, M. (2005). Plutonium activities and ${ }^{240} \mathrm{Pu} /{ }^{239} \mathrm{Pu}$ atom ratios in sediment cores from the east China sea and Okinawa Trough: Sources and inventories. Earth and Planetary Science Letters, 233, 441-453.

Wu, J., Zheng, J., Dai, M., Huh, C.-A., Chen, W., Tagami, K., \& Uchida, S. (2014). Isotopic composition and distribution of plutonium in northern South China Sea sediments revealed continuous release and transport of Pu from the Marshall Islands. Environmental Science and Technology, 48, 3136-3144.

Yamada, M., \& Nagaya, Y. (2000). Vertical profiles, inventories, and activity ratios of ${ }^{239+240} \mathrm{Pu}$ and ${ }^{137} \mathrm{Cs}$ in sediments from Sagami Bay, Western Northwest Pacific Margin. Journal of Radioanalytical and Nuclear Chemistry, 246, 369-378.

Zheng, J., \& Yamada, M. (2004). Sediment core record of global fallout and Bikini close-in fallout Pu in Sagami Bay, Western Northwest Pacific margin. Environmental Science and Technology, 38, 3498-3504. 

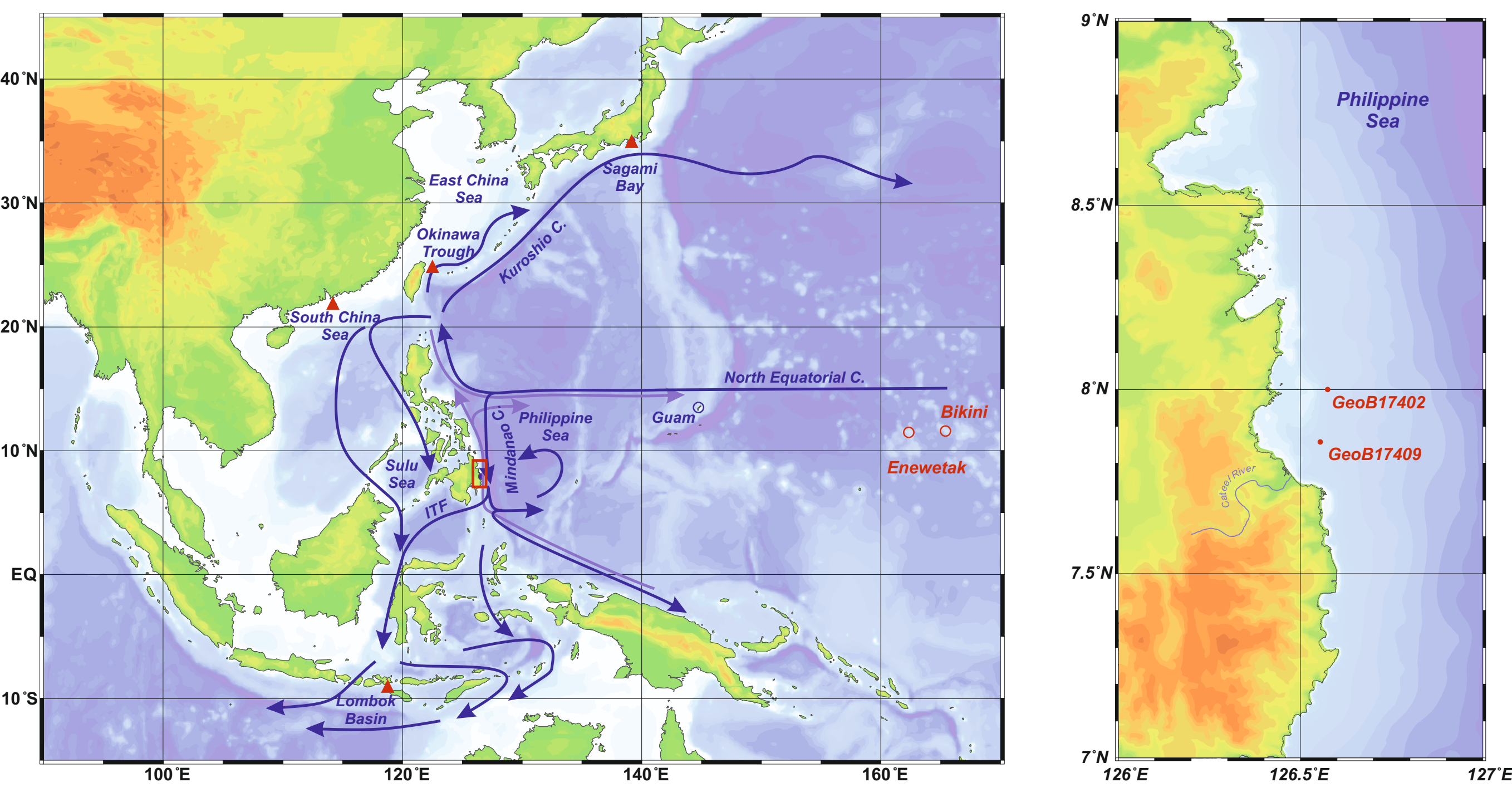
GeoB 17402

${ }^{210} \mathrm{~Pb}_{\mathrm{xs}}$ (Bq/kg d.m.)
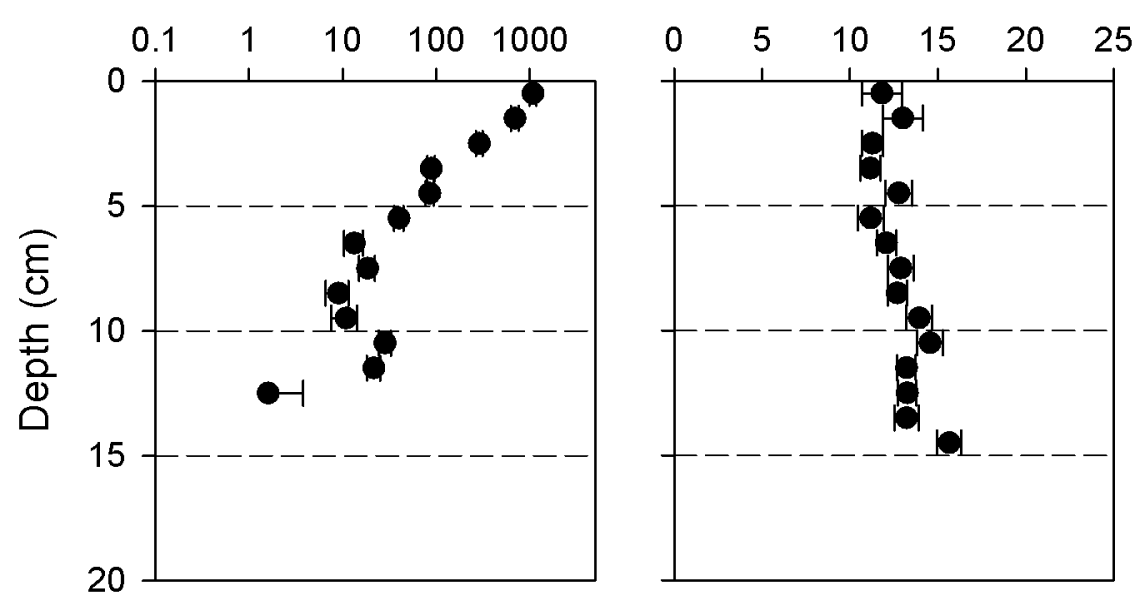

GeoB 17409

${ }^{210} \mathrm{~Pb}_{\mathrm{xs}}$ (Bq/kg d.m.)

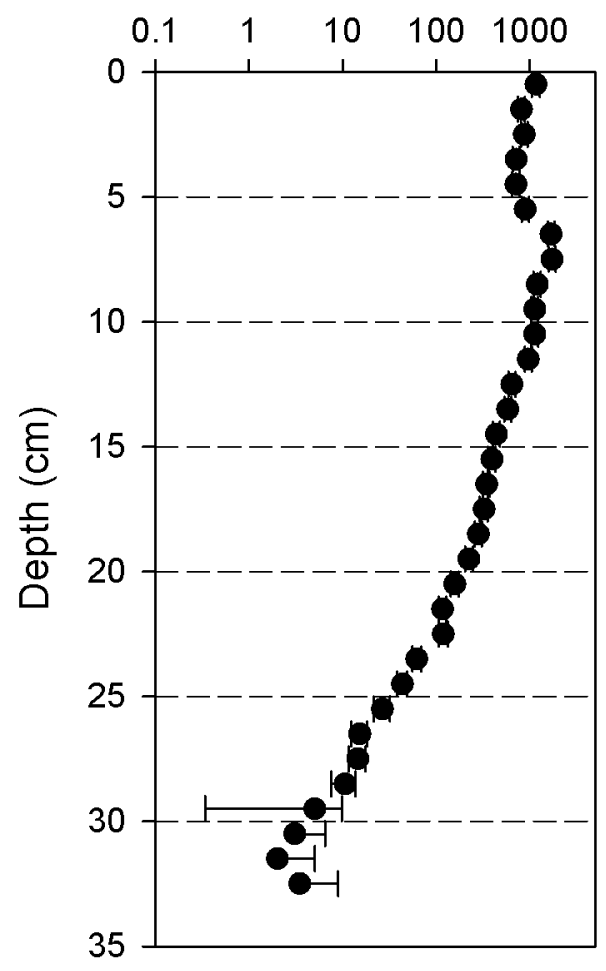

${ }^{226} \mathrm{Ra}$ (Bq/kg d.m.)

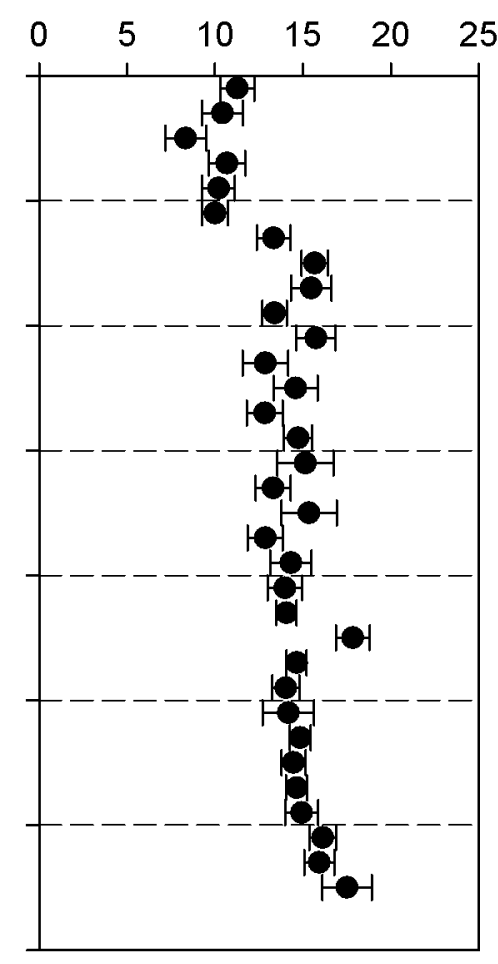

${ }^{228} \mathrm{Ra}$ and ${ }^{228} \mathrm{Th}$ (Bq/kg d.m.)

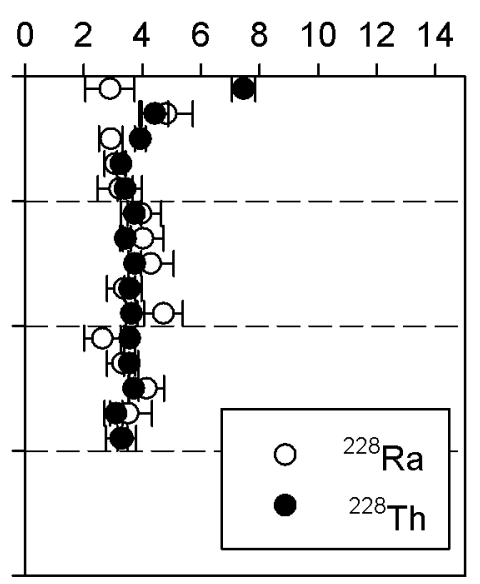

${ }^{228} \mathrm{Ra}$ and ${ }^{228} \mathrm{Th}$ (Bq/kg d.m.)

${ }^{228}$ Th_xs (Bq/kg d.m.)

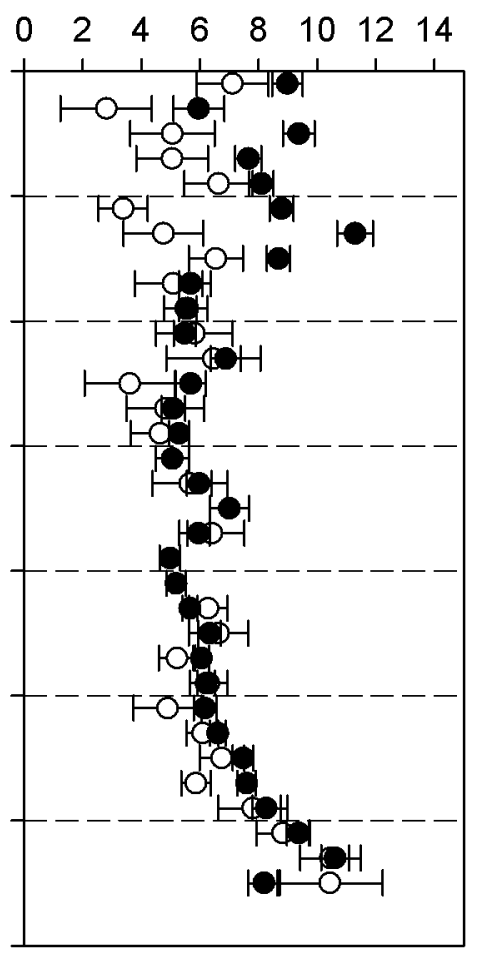

${ }^{228}$ Th_xs (Bq/kg d.m.)

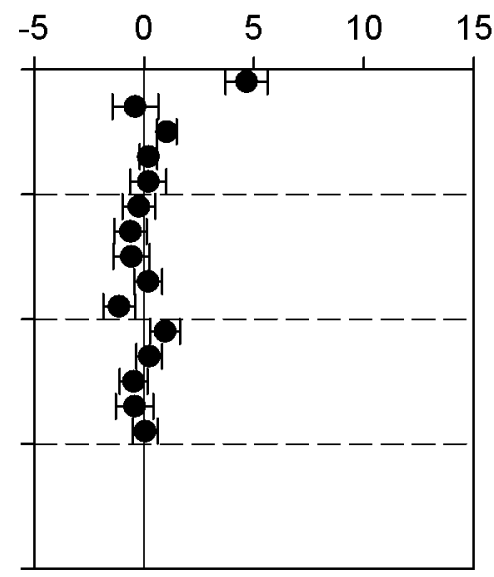

${ }^{40} \mathrm{~K}$ (Bq/kg d.m.)

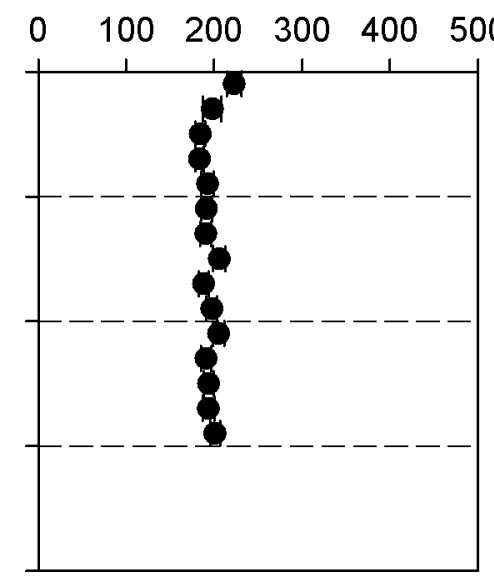

${ }^{40} \mathrm{~K}$ (Bq/kg d.m.)

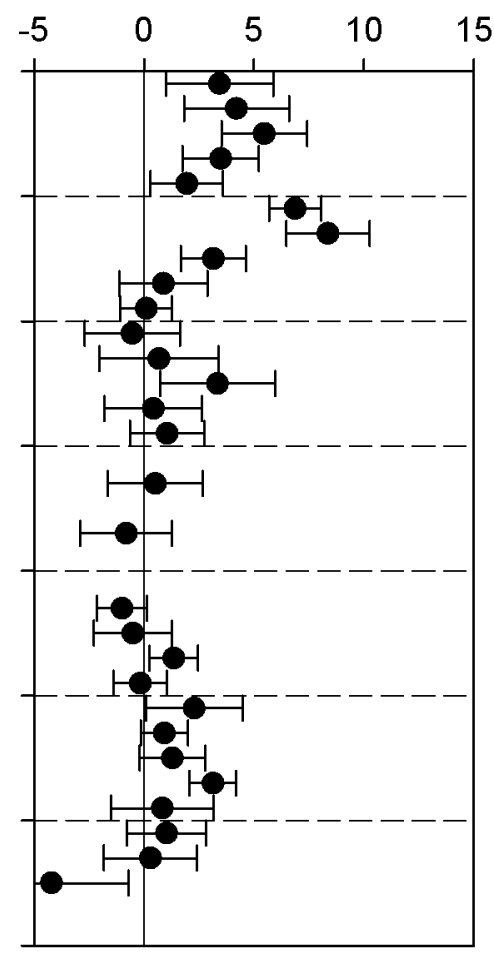

$\begin{array}{llllll}0 & 100 & 200 & 300 & 400 \quad 500\end{array}$

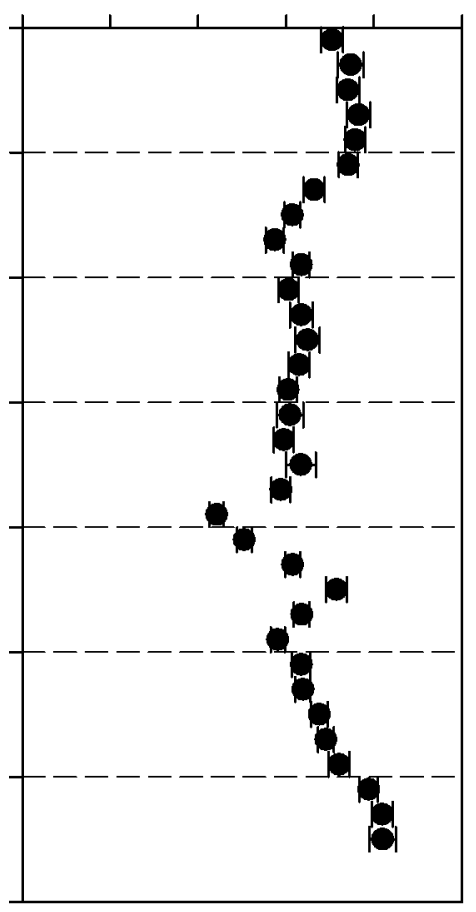


C ${ }^{238} \mathrm{Pu} / /^{239+240} \mathrm{Pu}$

$1 \quad{ }^{240} \mathrm{Pu} /{ }^{239} \mathrm{Pu}$ atom ratio
B Fraction PPG

$\begin{array}{llllll}0.15 & 0.20 & 0.25 & 0.30 & 0.35 & 0.40\end{array}$

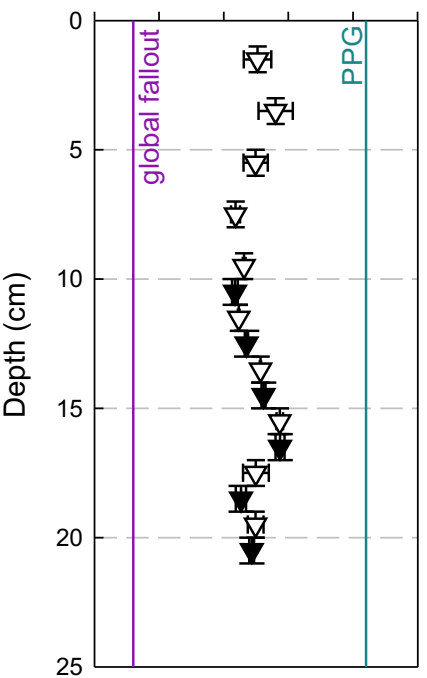

$0.2 \quad 0.4 \quad 0.6$

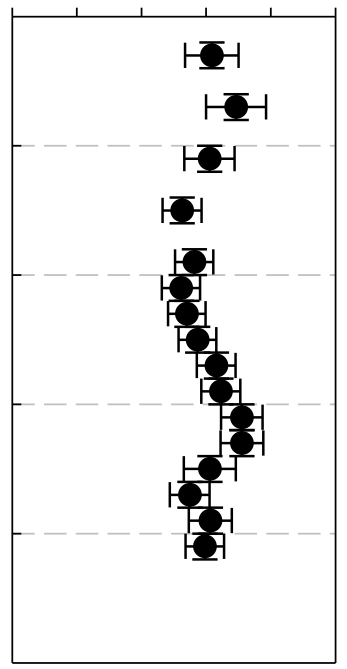

activity ratio

$\begin{array}{lll}0.01 & 0.02 & 0.03\end{array}$

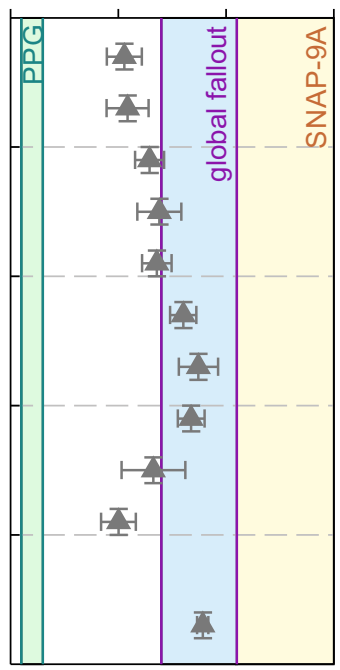




\section{Highlights}

- Radionuclide depth profiles were studied in sediment cores from the Philippine Sea.

- ${ }^{210} \mathrm{~Pb}_{x s},{ }^{228} \mathrm{Th}_{x s}$ and artificial radionuclides provided the age model.

- Very hight particle reactive radionulide inventories were found due to boundary scavenging.

- The contribution of plutonium from the Pacific Proving Grounds is at least $60 \%$.

- Both radionuclide and bulk organic geochemistry identified a sediment layer related to 2012 typhoon Bopha. 


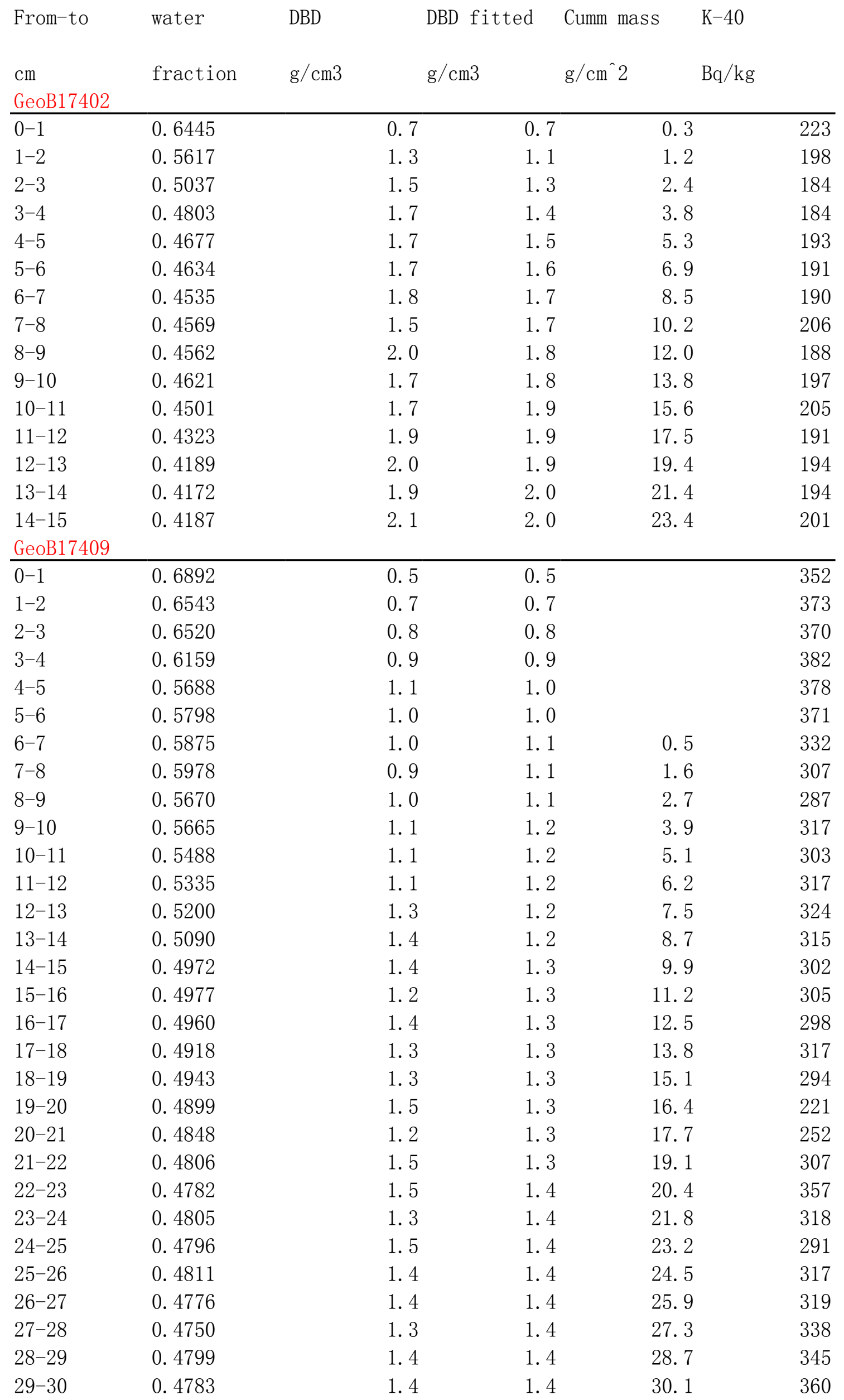




$\begin{array}{llllll}30-31 & 0.4962 & 1.4 & 1.4 & 31.6 & 394 \\ 31-32 & 0.4957 & 1.3 & 1.4 & 33.0 & 409 \\ 32-33 & 0.4768 & 0.9 & 1.4 & 34.4 & 410\end{array}$




\begin{tabular}{|c|c|c|c|c|}
\hline uncert & T1-208 & uncert & $\mathrm{Pb}-210$ & uncert \\
\hline $\mathrm{Bq} / \mathrm{kg}$ & $\mathrm{Bq} / \mathrm{kg}$ & $\mathrm{Bq} / \mathrm{kg}$ & $\mathrm{Bq} / \mathrm{kg}$ & $\mathrm{Bq} / \mathrm{kg}$ \\
\hline
\end{tabular}

\begin{tabular}{rrrrrr}
\hline 8 & 3.15 & 0.34 & 1074 & 87 & 7.5 \\
10 & 1.07 & 0.27 & 698 & 64 & 4.4 \\
5 & 1.21 & 0.10 & 296 & 24 & 3.9 \\
5 & 0.96 & 0.08 & 99 & 8 & 3.3 \\
7 & 1.31 & 0.24 & 97 & 9 & 3.4 \\
6 & 1.53 & 0.13 & 51 & 4 & 3.7 \\
6 & 1.23 & 0.22 & 25 & 3 & 3.4 \\
7 & 1.42 & 0.24 & 31 & 3 & 3.7 \\
6 & 1.12 & 0.17 & 22 & 2 & 3.6 \\
6 & 1.32 & 0.20 & 25 & 3 & 3.6 \\
6 & 1.24 & 0.16 & 42 & 4 & 3.6 \\
6 & 1.81 & 0.19 & 34 & 3 & 3.6 \\
6 & 1.33 & 0.17 & 15 & 2 & 3.7 \\
7 & 1.03 & 0.21 & 10 & 3 & 3.1 \\
6 & 1.22 & 0.12 & 11 & 2 & 3.3
\end{tabular}

\begin{tabular}{rrrrrr}
\hline 13 & 3.4 & 0.4 & 1123 & 112 & 9.0 \\
15 & 3.4 & 0.7 & 813 & 68 & 6.0 \\
13 & 2.2 & 0.5 & 870 & 72 & 9.4 \\
13 & 3.1 & 0.4 & 712 & 59 & 7.7 \\
12 & 2.6 & 0.4 & 710 & 57 & 8.1 \\
11 & 2.9 & 0.4 & 894 & 79 & 8.8 \\
12 & 3.5 & 0.4 & 1685 & 136 & 11.3 \\
9 & 3.0 & 0.3 & 1700 & 139 & 8.7 \\
10 & 1.6 & 0.3 & 1185 & 101 & 5.7 \\
9 & 2.0 & 0.2 & 1114 & 91 & 5.6 \\
11 & 1.9 & 0.3 & 1109 & 98 & 5.5 \\
13 & 1.7 & 0.5 & 946 & 77 & 6.9 \\
14 & 2.2 & 0.5 & 639 & 53 & 5.7 \\
12 & 2.3 & 0.4 & 576 & 48 & 5.1 \\
10 & 1.9 & 0.3 & 441 & 36 & 5.3 \\
15 & 1.6 & 0.5 & 396 & 35 & 5.1 \\
11 & 1.5 & 0.4 & 347 & 29 & 6.0 \\
17 & 1.8 & 0.6 & 329 & 30 & 7.0 \\
10 & 1.6 & 0.4 & 283 & 24 & 6.0 \\
8 & 1.1 & 0.4 & 231 & 20 & 5.0 \\
8 & 2.0 & 0.3 & 167 & 15 & 5.2 \\
8 & 1.9 & 0.2 & 127 & 10 & 5.7 \\
12 & 2.7 & 0.3 & 133 & 13 & 6.3 \\
9 & 1.7 & 0.2 & 75 & 6.0 \\
8 & 1.7 & 0.2 & 56 & 5 & 6.2 \\
11 & 2.4 & 0.4 & 40 & 5 & 6.2 \\
8 & 2.0 & 0.2 & 29 & 3 & 6.6 \\
10 & 2.4 & 0.3 & 28 & 3 & 7.5 \\
9 & 2.3 & 0.2 & 25 & 3 & 7.6 \\
12 & 3.2 & 0.4 & 20 & 4 & 8.3
\end{tabular}




$\begin{array}{rrrrrr}11 & 3.3 & 0.3 & 19 & 3 & 9.4 \\ 12 & 3.5 & 0.3 & 18 & 3 & 10.6 \\ 15 & 3.2 & 0.6 & 21 & 5 & 8.2\end{array}$




$\begin{array}{cccccl}\text { uncert } & \mathrm{Pb}-214 & \text { uncert } & \mathrm{Ac}-228 & \text { uncert } & 210 \mathrm{~Pb}-\mathrm{xs} \\ & (352 \mathrm{keV}) & & (911 \mathrm{keV}) & & \begin{array}{l}\text { decay correct } \\ \mathrm{Bq} / \mathrm{kg}\end{array} \\ \mathrm{Bq} / \mathrm{kg} & \mathrm{Bq} / \mathrm{kg} & \mathrm{Bq} / \mathrm{kg} & \mathrm{Bq} / \mathrm{kg} & \mathrm{Bq} / \mathrm{kg}\end{array}$

\begin{tabular}{rrrrrr}
\hline 0.4 & 11.8 & 1.1 & 2.9 & 0.8 & 1087 \\
0.5 & 13.0 & 1.1 & 4.8 & 0.9 & 698 \\
0.2 & 11.3 & 0.6 & 2.9 & 0.4 & 292 \\
0.1 & 11.2 & 0.6 & 3.1 & 0.4 & 89 \\
0.3 & 12.8 & 0.8 & 3.2 & 0.8 & 86 \\
0.2 & 11.2 & 0.7 & 4.0 & 0.7 & 40 \\
0.2 & 12.1 & 0.5 & 4.0 & 0.7 & 13 \\
0.2 & 12.9 & 0.7 & 4.3 & 0.8 & 19 \\
0.2 & 12.7 & 0.6 & 3.4 & 0.6 & 9 \\
0.2 & 13.9 & 0.7 & 4.7 & 0.7 & 11 \\
0.2 & 14.5 & 0.7 & 2.6 & 0.6 & 29 \\
0.2 & 13.2 & 0.5 & 3.3 & 0.5 & 22 \\
0.2 & 13.3 & 0.5 & 4.1 & 0.6 & 2 \\
0.2 & 13.2 & 0.7 & 3.5 & 0.8 & -3 \\
0.2 & 15.7 & 0.7 & 3.3 & 0.5 & -5
\end{tabular}

\begin{tabular}{rrrrrr}
\hline 0.5 & 11.3 & 1.0 & 7.1 & 1.2 & 1172 \\
0.9 & 10.4 & 1.2 & 2.8 & 1.6 & 822 \\
0.5 & 8.3 & 1.1 & 5.1 & 1.4 & 880 \\
0.4 & 10.7 & 1.0 & 5.1 & 1.2 & 720 \\
0.4 & 10.2 & 0.9 & 6.6 & 1.2 & 717 \\
0.4 & 10.0 & 0.7 & 3.4 & 0.8 & 903 \\
0.6 & 13.3 & 1.0 & 4.8 & 1.4 & 1707 \\
0.4 & 15.7 & 0.7 & 6.5 & 0.9 & 1741 \\
0.4 & 15.5 & 1.2 & 5.1 & 1.3 & 1209 \\
0.3 & 13.4 & 0.7 & 5.5 & 0.7 & 1138 \\
0.4 & 15.7 & 1.1 & 5.8 & 1.3 & 1138 \\
0.5 & 12.9 & 1.3 & 6.5 & 1.6 & 971 \\
0.5 & 14.6 & 1.3 & 3.6 & 1.5 & 650 \\
0.4 & 12.8 & 1.0 & 4.8 & 1.3 & 586 \\
0.3 & 14.7 & 0.8 & 4.6 & 1.0 & 444 \\
0.6 & 15.1 & 1.6 & & & 397 \\
0.4 & 13.3 & 1.0 & 5.7 & 1.3 & 347 \\
0.7 & 15.3 & 1.6 & & & 326 \\
0.4 & 12.9 & 1.0 & 6.4 & 1.1 & 284 \\
0.4 & 14.3 & 1.2 & & & 226 \\
0.3 & 14.0 & 1.0 & & & 159 \\
0.3 & 14.1 & 0.6 & 6.3 & 0.7 & 118 \\
0.4 & 17.8 & 1.0 & 6.6 & 1.0 & 120 \\
0.3 & 14.6 & 0.6 & 5.2 & 0.6 & 63 \\
0.3 & 14.0 & 0.8 & 6.3 & 0.6 & 44 \\
0.4 & 14.2 & 1.5 & 4.9 & 1.2 & 27 \\
0.3 & 14.8 & 0.6 & 6.1 & 0.5 & 15 \\
0.3 & 14.5 & 0.7 & 6.7 & 0.8 & 15 \\
0.3 & 14.6 & 0.6 & 5.9 & 0.5 & 11 \\
0.5 & 14.9 & 0.9 & 7.8 & 1.2 & 5
\end{tabular}



0.4
16. 1
0.8
8. 8
0.9
3
$0.5 \quad 15.9$
0.9
10.5
1. 0
17.5
1.4
10. 4
1. 8
4 


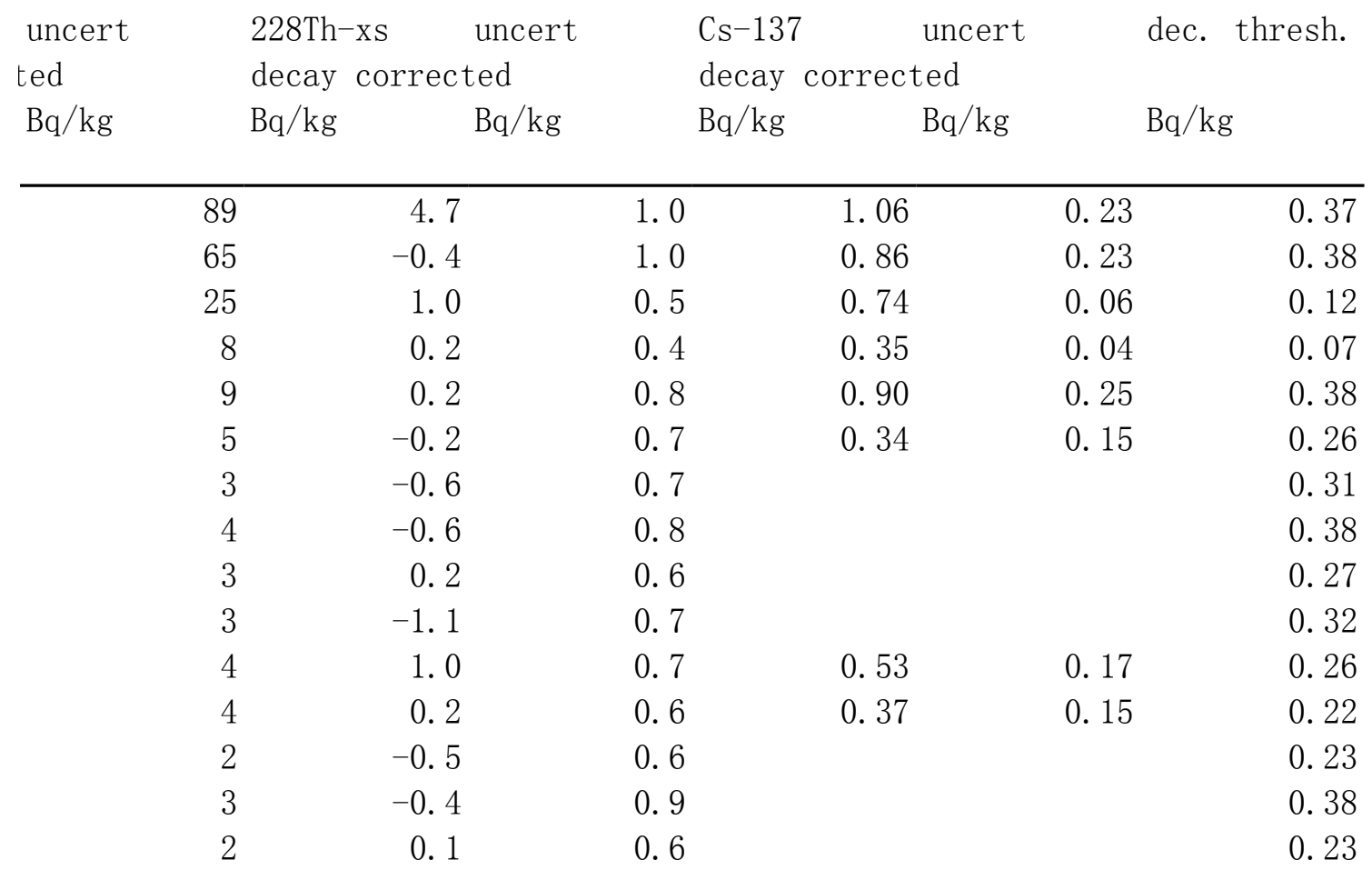

\begin{tabular}{|c|c|c|c|c|c|}
\hline 118 & 3.4 & 2.4 & 1.32 & 0.37 & 0.61 \\
\hline 69 & 4. 2 & 2.4 & 2. 79 & 0.56 & 0.89 \\
\hline 73 & 5.5 & 2.0 & 2. 08 & 0.41 & 0.65 \\
\hline 60 & 3.5 & 1.7 & 1.92 & 0.32 & 0.48 \\
\hline 59 & 1.9 & 1.6 & 1. 28 & 0.24 & 0.38 \\
\hline 80 & 6.9 & 1.2 & 1.60 & 0.17 & 0.27 \\
\hline 139 & 8.4 & 1.9 & 0.97 & 0.32 & 0.52 \\
\hline 143 & 3.2 & 1.5 & 1. 44 & 0.13 & 0.24 \\
\hline 105 & 0.9 & 2.0 & 1. 81 & 0.38 & 0.60 \\
\hline 94 & 0.1 & 1.2 & 1. 79 & 0.21 & 0.31 \\
\hline 102 & -0.5 & 2.2 & 1. 59 & 0.39 & 0.60 \\
\hline 80 & 0.7 & 2.7 & 2. 52 & 0.40 & 0.57 \\
\hline 55 & 3.3 & 2.6 & 2.56 & 0.56 & 0.85 \\
\hline 50 & 0.4 & 2.2 & 2.65 & 0.38 & 0.56 \\
\hline 38 & 1.1 & 1.7 & 2. 36 & 0.27 & 0.35 \\
\hline 36 & & & 2. 09 & 0.50 & 0.70 \\
\hline 30 & 0.5 & 2.2 & 1. 59 & 0.31 & 0.44 \\
\hline 31 & & & 1.91 & 0.57 & 0.89 \\
\hline 25 & -0.8 & 2.1 & 1. 75 & 0.37 & 0.57 \\
\hline 21 & & & 0.92 & 0.29 & 0.45 \\
\hline 16 & & & & & 0.55 \\
\hline 11 & -1.0 & 1.1 & & & 0.27 \\
\hline 13 & -0.5 & 1.8 & & & 0.58 \\
\hline 7 & 1.4 & 1.1 & & & 0.25 \\
\hline 5 & -0.2 & 1.2 & & & 0.30 \\
\hline 5 & 2.3 & 2.2 & & & 0.56 \\
\hline 3 & 0.9 & 1.1 & & & 0.21 \\
\hline 3 & 1.3 & 1.5 & & & 0.35 \\
\hline 3 & 3.1 & 1.1 & & & 0.24 \\
\hline 5 & 0.8 & 2.3 & & & 0.63 \\
\hline
\end{tabular}




$\begin{array}{rrrr}3 & 1.0 & 1.8 & 0.33 \\ 3 & 0.3 & 2.1 & 0.43 \\ 5 & -4.2 & 3.5 & 0.54\end{array}$




\begin{tabular}{|c|c|c|c|}
\hline $\mathrm{Am}-241$ & uncert & dec. thresh. & $\begin{array}{l}\mathrm{Am} / \mathrm{Cs} \text { uncert } \\
\text { activity ratio }\end{array}$ \\
\hline $\mathrm{Bq} / \mathrm{kg}$ & $\mathrm{Bq} / \mathrm{kg}$ & $\mathrm{Bq} / \mathrm{kg}$ & \\
\hline
\end{tabular}

\begin{tabular}{|c|c|c|c|c|c|}
\hline 1.81 & 0.13 & 0.46 & 4.9 & 1.1 & \\
\hline 2. 13 & 0.24 & 0.79 & 5.8 & 1.7 & \\
\hline 1. 42 & 0.09 & 0.17 & 3.9 & 0.4 & \\
\hline 0.69 & 0.06 & 0.13 & 3.8 & 0.5 & \\
\hline 1.08 & 0.11 & 0.37 & 2.3 & 0.7 & \\
\hline 0.44 & 0.06 & 0.30 & 2.4 & 1. 1 & \\
\hline 0.11 & 0.09 & 0.28 & & & \\
\hline 0.35 & 0.06 & 0.33 & & & \\
\hline \multirow[t]{2}{*}{0.20} & 0.05 & 0.23 & & & \\
\hline & & 0.40 & & & \\
\hline 0.42 & 0.12 & 0.35 & 1.5 & 0.6 & \\
\hline \multirow[t]{4}{*}{0.20} & 0.12 & 0.35 & 1.0 & 0.7 & \\
\hline & & 0.28 & & & \\
\hline & & 0.45 & & & \\
\hline & & 0.29 & & & \\
\hline 1.7 & 0.6 & 0.9 & 1.4 & 0.6 & \\
\hline 2.1 & 0.3 & 0.8 & 0.8 & 0.2 & 2.00 \\
\hline 1.8 & 0.3 & 0.7 & 0.9 & 0.2 & \\
\hline 1.8 & 0.2 & 0.6 & 0.9 & 0.2 & 1.75 \\
\hline 1.8 & 0.2 & 0.5 & 1.4 & 0.3 & \\
\hline 1.7 & 0.4 & 0.5 & 1. 1 & 0.3 & 2. 03 \\
\hline 3.2 & 0.6 & 1.0 & 3. 4 & 1.3 & \\
\hline 5.2 & 0.5 & 0.6 & 3.7 & 0.5 & 4. 80 \\
\hline 4.4 & 0.7 & 1.1 & 2.5 & 0.7 & \\
\hline 7.5 & 0.6 & 0.5 & 4.3 & 0.6 & 6. 41 \\
\hline 8.0 & 0.8 & 0.9 & 5.2 & 1.4 & \\
\hline 9.3 & 0.8 & 0.8 & 3.9 & 0.7 & 9.04 \\
\hline 12.7 & 1.1 & 1.2 & 5.2 & 1.2 & \\
\hline 11.7 & 1. 0 & 1.0 & 4. 6 & 0.8 & 12.54 \\
\hline 10.5 & 0.8 & 0.8 & 4.6 & 0.6 & \\
\hline 7.5 & 1.0 & 1.3 & 3.7 & 1.0 & 7.88 \\
\hline 5.4 & 0.6 & 0.7 & 3.5 & 0.8 & \\
\hline 5.6 & 0.8 & 1.1 & 3.0 & 1.0 & 1.79 \\
\hline 6.2 & 0.6 & 0.6 & 3.8 & 0.9 & \\
\hline 3.3 & 0.7 & 1.1 & 3.7 & 1.4 & 3.89 \\
\hline 1.0 & 0.4 & 0.7 & & & \\
\hline \multirow[t]{9}{*}{0.3} & 0.1 & 0.2 & & & 0.41 \\
\hline & & 0.7 & & & \\
\hline & & 0.3 & & & 0.29 \\
\hline & & 0.4 & & & \\
\hline & & 0.8 & & & \\
\hline & & 0.2 & & & \\
\hline & & 0.4 & & & \\
\hline & & 0.3 & & & \\
\hline & & 0.8 & & & \\
\hline
\end{tabular}


0.4

0.5

0.7 


\begin{tabular}{llllll} 
uncert & $\begin{array}{l}23940 \mathrm{Pu} \\
\mathrm{ICP}-\mathrm{MS}\end{array}$ & uncert & 238Pu & uncert & $\begin{array}{l}\text { 238/239+40 } \\
\text { activity rati }\end{array}$ \\
$\mathrm{Bq} / \mathrm{kg}$ & $\mathrm{Bq} / \mathrm{kg}$ & $\mathrm{Bq} / \mathrm{kg}$ & $\mathrm{Bq} / \mathrm{kg}$ & $\mathrm{Bq} / \mathrm{kg}$ & \\
\hline
\end{tabular}

\begin{tabular}{|c|c|c|c|c|c|}
\hline 0.13 & 1.90 & 0.18 & 0.0212 & 0.0034 & 0.011 \\
\hline 0.13 & 1.60 & 0.17 & 0.0190 & 0.0035 & 0.011 \\
\hline 0.11 & 1.72 & 0.14 & 0.0261 & 0.0030 & 0.013 \\
\hline 0.37 & 4. 39 & 0.27 & 0.0663 & 0.0104 & 0.014 \\
\hline 0.38 & $\begin{array}{l}6.40 \\
6.80\end{array}$ & $\begin{array}{l}0.40 \\
0.34\end{array}$ & 0.0870 & 0.0098 & 0.014 \\
\hline 0.77 & $\begin{array}{r}8.73 \\
10.59\end{array}$ & $\begin{array}{l}0.54 \\
0.53\end{array}$ & 0.1450 & 0.0132 & 0.016 \\
\hline 0.93 & $\begin{array}{r}12.93 \\
9.97\end{array}$ & $\begin{array}{l}0.91 \\
0.50\end{array}$ & 0.2186 & 0.0253 & 0.017 \\
\hline 0.61 & $\begin{array}{l}6.57 \\
6.08\end{array}$ & $\begin{array}{l}0.47 \\
0.31\end{array}$ & 0.1322 & 0.0118 & 0.017 \\
\hline 0.12 & $\begin{array}{l}1.93 \\
4.40\end{array}$ & $\begin{array}{l}0.26 \\
0.22\end{array}$ & 0.0238 & 0.0054 & 0.013 \\
\hline 0.24 & $\begin{array}{l}4.01 \\
1.03\end{array}$ & $\begin{array}{l}0.33 \\
0.05\end{array}$ & 0.0390 & 0.0066 & 0.010 \\
\hline 0.05 & 0.64 & 0.38 & & & \\
\hline 0.04 & 0.28 & 0.23 & 0.0051 & 0.0003 & 0.018 \\
\hline
\end{tabular}





\begin{tabular}{lll} 
uncert & Pu240/239 uncert & Fraction $P P G$ uncert \\
io & & age \\
& & yr \\
\hline
\end{tabular}

\begin{tabular}{|c|c|c|c|c|c|}
\hline 0.002 & 0.276 & 0.011 & 0.62 & 0.08 & \\
\hline 0.002 & 0.290 & 0.013 & 0.69 & 0.09 & \\
\hline \multirow[t]{2}{*}{0.001} & 0.275 & 0.009 & 0.61 & 0.08 & \\
\hline & & & & & 2011 \\
\hline 0.002 & 0.259 & 0.003 & 0.53 & 0.06 & $\begin{array}{l}2007 \\
2002\end{array}$ \\
\hline \multirow[t]{2}{*}{0.001} & 0.266 & 0.001 & 0.56 & 0.06 & 1997 \\
\hline & 0.259 & 0.002 & 0.52 & 0.06 & 1992 \\
\hline \multirow[t]{2}{*}{0.001} & 0.262 & 0.001 & 0.54 & 0.06 & 1987 \\
\hline & 0.268 & 0.001 & 0.57 & 0.06 & 1981 \\
\hline \multirow[t]{2}{*}{0.002} & 0.278 & 0.000 & 0.63 & 0.06 & 1976 \\
\hline & 0.281 & 0.002 & 0.65 & 0.06 & 1971 \\
\hline \multirow[t]{2}{*}{0.001} & 0.293 & 0.003 & 0.71 & 0.06 & 1965 \\
\hline & 0.294 & 0.004 & 0.71 & 0.07 & 1960 \\
\hline \multirow[t]{2}{*}{0.003} & 0.275 & 0.010 & 0.61 & 0.08 & 1954 \\
\hline & 0.263 & 0.004 & 0.55 & 0.06 & 1949 \\
\hline \multirow[t]{4}{*}{0.002} & 0.275 & 0.006 & 0.61 & 0.07 & 1943 \\
\hline & 0.272 & 0.002 & 0.60 & 0.06 & 1937 \\
\hline & & & & & 1932 \\
\hline & & & & & 1926 \\
\hline \multirow[t]{7}{*}{0.001} & & & & & 1913 \\
\hline & & & & & 1900 \\
\hline & & & & & 1887 \\
\hline & & & & & 1874 \\
\hline & & & & & 1861 \\
\hline & & & & & 1848 \\
\hline & & & & & 1835 \\
\hline
\end{tabular}


1822

1808

1795 


\begin{tabular}{lllll} 
uncert & TOC & uncert & d13C & uncert \\
yr & $\%$ & $\%$ & per mil & per mil \\
\hline
\end{tabular}

\begin{tabular}{lllll}
\hline & 1.449 & 0.010 & -24.68 & 0.33 \\
& 1.366 & 0.016 & -24.86 & 0.65 \\
& 1.368 & 0.027 & -25.61 & 0.16 \\
& 1.276 & 0.003 & -25.94 & 0.54 \\
& 1.183 & 0.013 & -26.16 & 0.37 \\
0 & 1.258 & 0.018 & -26.04 & 0.39 \\
0 & 1.291 & 0.011 & -23.79 & 0.51 \\
1 & 1.312 & 0.011 & -23.04 & 0.19 \\
1 & 1.205 & 0.006 & -22.11 & 0.38 \\
1 & 1.239 & 0.007 & -22.58 & 0.12 \\
2 & 1.365 & 0.002 & -21.55 & 0.18 \\
2 & 1.288 & 0.009 & -22.62 & 0.74 \\
2 & 1.350 & 0.021 & -23.69 & 0.01 \\
2 & 1.274 & 0.006 & -23.38 & 0.17 \\
3 & 1.352 & 0.010 & -23.62 & 0.15 \\
3 & 1.368 & 0.025 & -23.08 & 0.76 \\
3 & 1.314 & 0.005 & -23.25 & 0.19 \\
4 & 1.278 & 0.051 & -23.69 & 0.21 \\
4 & 1.291 & 0.010 & -23.79 & 0.05 \\
4 & 1.208 & 0.012 & -23.52 & 0.27 \\
5 & 1.179 & 0.015 & -22.84 & 0.16 \\
5 & 1.181 & 0.041 & -23.21 & 0.45 \\
5 & 1.192 & 0.022 & -23.29 & 0.53 \\
6 & 1.228 & 0.005 & -23.61 & 0.09 \\
7 & 1.214 & 0.025 & -22.04 & 0.55 \\
7 & 1.234 & 0.004 & -22.62 & 0.08 \\
8 & 1.127 & 0.004 & -23.85 & 0.12 \\
9 & 1.085 & 0.001 & -24.05 & 0.01 \\
9 & 1.050 & 0.022 & -24.36 & 0.18
\end{tabular}




$\begin{array}{lllll}10 & 1.047 & 0.005 & -23.55 & 0.03 \\ 10 & 1.044 & 0.008 & -24.15 & 0.09 \\ 11 & 1.165 & 0.025 & -23.72 & 0.34\end{array}$


Supplementary on-line material: Pacific Proving Grounds radioisotope imprint in the Philippine Sea sediments

April 7, 2017 


\section{Gamma spectrometry additional information}

Tab. S1 contains detailed information on slicing of the cores, masses of samples and counting times of gamma spectra. The average water contents were $47 \%$ (42-64\%) in core GeoB17402 and 59\% (47-69\%) in core GeoB17409.

Table S1: Summary of samples measurement data

\begin{tabular}{llcc}
\hline Sediment core & Slices & $\begin{array}{c}\text { Sample wet mass }(\mathrm{g}) \\
\text { mean }(\min -\max )\end{array}$ & $\begin{array}{c}\text { Live-time }(\mathrm{h}) \\
\operatorname{mean}(\min -\max )\end{array}$ \\
\hline GeoB 17402 & $1 \mathrm{~cm}$ slices, depth $0-16 \mathrm{~cm}$ & $87(45-102)$ & $55(24-171)$ \\
GeoB 17409 & $1 \mathrm{~cm}$ slices, depth $0-33 \mathrm{~cm}$ & $72(47-83)$ & $47(6-162)$ \\
\hline
\end{tabular}

The ${ }^{210} \mathrm{~Pb}_{\text {sup }}$ values were derived from the concentrations of ${ }^{226} \mathrm{Ra}$, measured via the concentration of the strongest line of its daughter product ${ }^{214} \mathrm{~Pb}$ at an energy of $352 \mathrm{keV}$. Excess ${ }^{210} \mathrm{~Pb}\left({ }^{210} \mathrm{~Pb}_{x s}\right)$ values were calculated by subtracting supported ${ }^{210} \mathrm{~Pb}$ from total ${ }^{210} \mathrm{~Pb}$ determined via its $46 \mathrm{keV}$ gamma line. Activity concentrations of ${ }^{228} \mathrm{Ra}$ and ${ }^{228} \mathrm{Th}$ were derived from the daughter isotopes in equilibrium ${ }^{228} \mathrm{Ac}$ $(911 \mathrm{keV})$ and ${ }^{212} \mathrm{~Pb}(239 \mathrm{keV})$, respectively. In case of the $239 \mathrm{keV}$ line, care was taken to deconvolute from the close $242 \mathrm{keV}$ line of ${ }^{214} \mathrm{~Pb} .{ }^{137} \mathrm{Cs}$ was determined via its ${ }^{137 m} \mathrm{Ba}$ line at $662 \mathrm{keV},{ }^{241} \mathrm{Am}$ via the $60 \mathrm{keV}$ line and ${ }^{40} \mathrm{~K}$ via its $1461 \mathrm{keV}$ line. Cascade summing corrections were performed for ${ }^{228} \mathrm{Ac}$ using Genie 2000. ${ }^{210} \mathrm{~Pb}_{x s},{ }^{228} \mathrm{Th}_{x s}$ and ${ }^{137} \mathrm{Cs}$ activities were decay corrected to the sampling date (2013). All other isotopes do not need correction (long half-lives or are in equilibrium with a long-lived isotope) or are reported to the measurement date (2014), because the activity of their parent nuclide was not known.

\section{$2 \quad$ Dry bulk density}

Dry bulk density (Fig. S1) was calculated from dry mass of the entire sediment slice divided by the constant volume of $28.3 \mathrm{~cm}^{3}$, representing the sampler diameter of $6 \mathrm{~cm}$ and slice thickness of $1 \mathrm{~cm}$. To correct for small irregularities in slice thicknesses, the measured values were fitted with a logarithmic function and the fitted values were used for further calculations. The bottommost sample in core GeoB17409 was excluded from the fit - the slice was incomplete. 


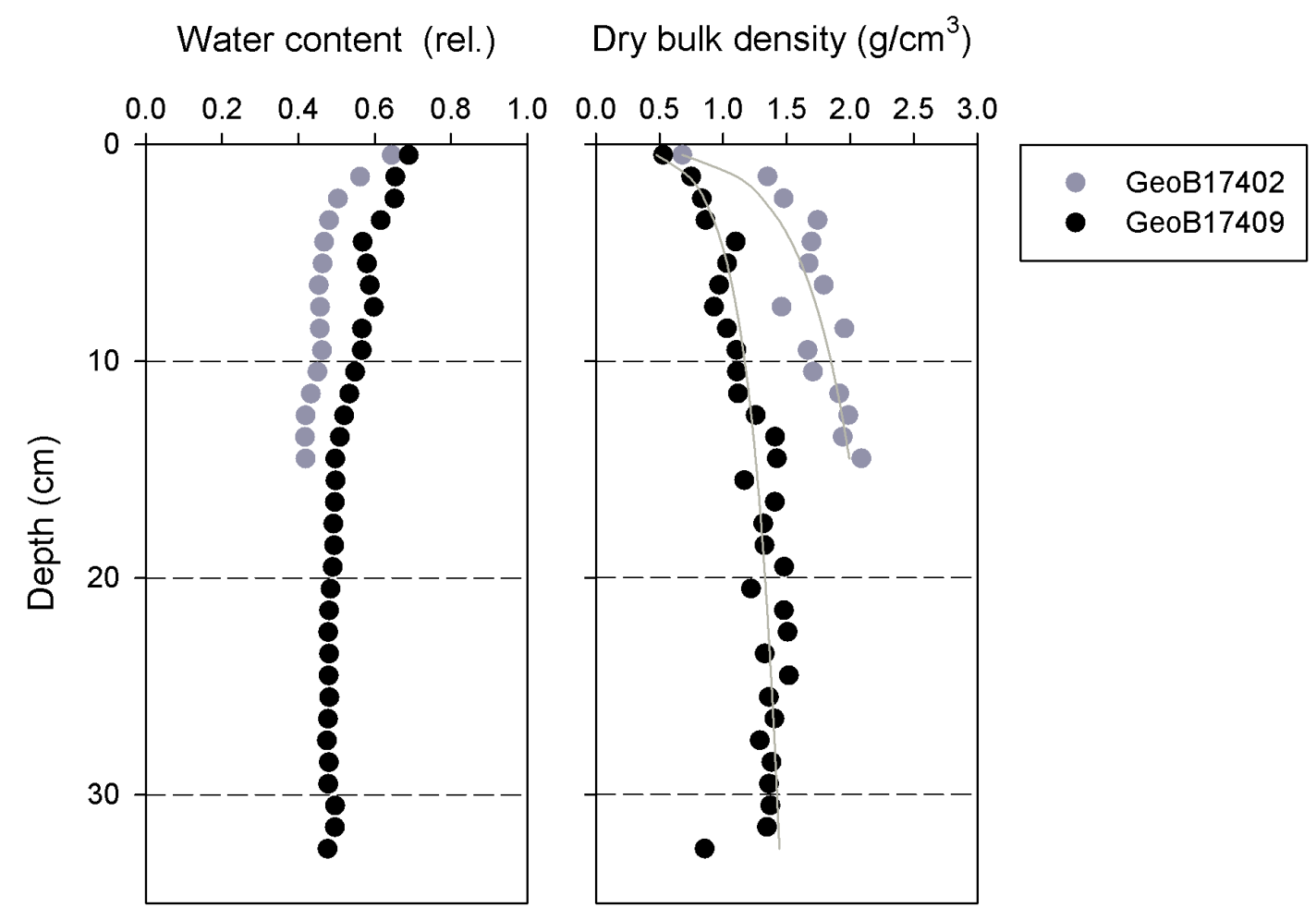

Figure S1: Depth profiles of water content and dry bulk density in studied cores. 


\title{
Pacific Proving Grounds radioisotope imprint in the Philippine Sea sediments
}

\author{
Daniela Pittauer ${ }^{\mathrm{a}, 1, *}$, Per Roos $^{\mathrm{c}}$, Jixin Qiao $^{\mathrm{c}}$, Walter Geibert ${ }^{\mathrm{d}}$, Marcus Elvert ${ }^{\mathrm{a}}$, Helmut W. Fischer ${ }^{\mathrm{b}}$ \\ ${ }^{a}$ University of Bremen, MARUM - Center for Marine Environmental Sciences, Leobener Str. 8, D-28359 Bremen, Germany \\ ${ }^{b}$ University of Bremen, Institute for Environmental Physics, Otto-Hahn-Allee 1, D-28359 Bremen, Germany \\ ${ }^{c}$ Danish Technical University, NUTECH, Roskilde, Denmark \\ ${ }^{d}$ Alfred Wegener Institute for Marine and Polar Research, Bremerhaven, Germany
}

\begin{abstract}
Radionuclide concentrations were studied in sediment cores taken at the continental slope of the Philippine Sea off Mindanao Island in the equatorial Western Pacific. High resolution deposition records of anthropogenic radionuclides were collected at this site. Excess ${ }^{210} \mathrm{~Pb}$ together with excess ${ }^{228} \mathrm{Th}$ and anthropogenic radionuclides provided information about accumulation rates. Concentrations of $\mathrm{Am}$ and $\mathrm{Pu}$ isotopes were detected by gamma spectrometry, alpha spectrometry and ICP-MS. The Pu ratios indicate a high portion (minimum of 60\%) of Pu from the Pacific Proving Grounds (PPG). This implies that the transport of PPG derived plutonium with the Mindanao Current southward is similarly effective as the previously known transport towards the north with the Kuroshio Current. The record is compared to other studies from northwest Pacific marginal seas and Lombok basin in the Indonesian Archipelago. The sediment core top was found to contain a $6 \mathrm{~cm}$ thick layer dominated by terrestrial organic matter, which was interpreted as a result of the 2012 Typhoon Pablo-related fast deposition.
\end{abstract}

Keywords: ${ }^{241} \mathrm{Am},{ }^{137} \mathrm{Cs}$, plutonium, excess ${ }^{228} \mathrm{Th}$, typhoon, Pacific Ocean

${ }^{*}$ Corresponding author.

Email address: pitdana@yahoo.co.uk (Daniela Pittauer) 